CEP Discussion Paper No 717

March 2006

\title{
Trade Liberalization and Industrial Restructuring through Mergers and Acquisitions \\ Holger Breinlich
}

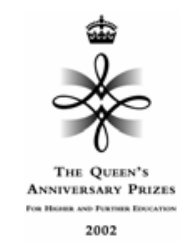




\begin{abstract}
This paper analyzes mergers and acquisitions (M\&A) as a previously neglected channel of industrial restructuring in the face of trade liberalization. Using the Canada-United States Free Trade Agreement of 1989 as a natural experiment, I show that trade liberalization leads to a significant increase in M\&A activity. I also provide evidence that resources are transferred from less to more productive firms in the process and that the magnitude of the overall transfer is quantitatively important. Taken together, these results suggest that M\&A is an important alternative to the previously studied adjustment channels of firm and establishment closure and contraction. This has strong implications for the design of competition policy in the wake of trade liberalizations since M\&A may offer a more efficient way of transferring resources than contraction and closure of low productivity firms combined with internal growth of more efficient firms.
\end{abstract}

Keywords: Mergers and Acquisitions, Trade Liberalization, International Trade, CUSFTA JEL Classification Nos: F12, F15, L2, L4

Data: Compustat North America; Compustat Global; Thomson Financial Worldwide M\&A Database; tariffs and number of establishments by industry from Statistics Canada and the NBER.

This paper was produced as part of the Centre's Globalisation Programme. The Centre for Economic Performance is financed by the Economic and Social Research Council.

\title{
Acknowledgements
}

I am grateful to Stephen Redding, Keith Head, Anthony Venables, Henry Overman, Silvana Tenreyro and seminar participants at the London School of Economics, the University of Nottingham, the University of Bristol, the NEG Spring School 2005 in Cagliari, and the ETSG Meeting 2005 in Dublin for helpful comments and suggestions. All remaining errors are mine.

Published by

Centre for Economic Performance

London School of Economics and Political Science

Houghton Street

London WC2A $2 \mathrm{AE}$

All rights reserved. No part of this publication may be reproduced, stored in a retrieval system or transmitted in any form or by any means without the prior permission in writing of the publisher nor be issued to the public or circulated in any form other than that in which it is published.

Requests for permission to reproduce any article or part of the Working Paper should be sent to the editor at the above address.

(C) H. Breinlich, submitted 2006

ISBN 0753019434 


\section{Introduction}

Recent economic research on the effects of trade liberalization has highlighted the importance of studying the firm- and establishment-level adjustment processes triggered by freer trade (a short and inexhaustive list of contributions includes Tybout et al., 1991; Tybout and Westbrook, 1995; Pavcnik, 2002; and Trefler, 2004). A central insight from these studies is that a substantial part of the impact of freer trade works through a reallocation of resources across individual plants and firms. In particular, the contraction and exit of low productivity establishments and the expansion of more productive ones can explain a sizeable share of aggregate productivity increases found in the wake of trade liberalizations (see Pavcnik, 2002; and Trefler, 2004).

While this literature has thus demonstrated the general importance of micro-level resource reallocation in understanding the effects of freer trade, the central issue of how resources are transferred between individual firms is still not sufficiently well understood. In particular, only scarce attention has been paid to resource transfers through the market for corporate control, i.e. through mergers and acquisitions (M\&A). This is despite the fact that M\&A can, in principle, play a similar role as the adjustment processes highlighted in the existing literature. Instead of closing down establishments, reducing output or exiting altogether, firms also have the option to search for buyers interested in parts or the whole of their operations. Similarly, expanding firms can buy and integrate other firms rather than expand production at existing plants or open new ones. Establishmentlevel studies which focus on plant-level contraction, exit or expansion implicitly ignore this potential margin of adjustment since they do not look at changes in ownership at continuing plants. ${ }^{1}$

The purpose of this paper is to investigate empirically whether M\&A does indeed play a role in industrial restructuring in the face of trade liberalization. This is important for a number of reasons. First, studying M\&A is necessary to obtain a more complete picture of the mechanisms firms use to adjust to freer trade and of the extent of inter-firm resource transfers involved in this adjustment. Second, M\&A is not just another way of transferring resources but is likely to be qualitatively different from the other adjustment forms in that it is swifter and potentially more efficient. Instead of workers and capital becoming unemployed for some period before being rehired, acquisitions allow for an immediate transfer into new ownership. Also, M\&A allows the takeover of entire production structures which may be most efficient if preserved as a whole. Finally, knowing whether or not M\&A plays an important role in firm adjustment to freer trade might also shed new light on results from previous plant-level studies. For example, reallocations

\footnotetext{
${ }^{1}$ Similarly, a smaller group of papers that use firms rather than plants or establishments as their unit of analysis focus on exit by bankruptcy as the principal form of adjustment and do not consider M\&A (see for example Gu, 2003; or Baggs, 2004). Note that throughout this paper, I will use the words "establishment" and "plant" interchangeably to denote a unit of production within a firm.
} 
of control rights at existing establishments and ensuing restructuring undertaken by the new management might be part of the reason for the important within-plant increases in productivity found in many studies (e.g. Tybout and Westbrook, 1995; Pavcnik, 2002).

The particular liberalization episode I will study in this paper is the Canada-United States Free Trade Agreement (CUSFTA) of 1989. As will be argued in more detail, CUSFTA provides an ideal setting for the purpose of this study. Most importantly, it represented a clear-cut and unanticipated policy experiment which was not introduced in response to macroeconomic shocks nor accompanied by other major economic reforms. Furthermore, the main policy instrument used (tariff cuts) is easily quantifiable and shows a large variation across sectors. Finally, the large size difference between the treaty partners and the implied variation in expected responses to the integration shock further increases the potential for convincing econometric identification.

Against this background, I will present three main sets of findings. In a first step, I examine whether there is evidence that CUSFTA led to more M\&A activity. Using a difference-in-differences approach, I find a substantial increase in the number of domestic Canadian transactions which is positively correlated with the magnitude of tariff cuts across sectors. There is also an effect on domestic U.S. M\&A activity but one that is much less pronounced than in Canada, consistent with the idea that CUSFTA presented the bigger shock for the smaller Canadian market. Cross-border transactions show substantial changes around the implementation of CUSFTA as well, although the link to tariff cuts is less clear cut. In a second step, I examine firm-level characteristics of targets and acquirers in order to investigate whether acquisitions involve a transfer of resources from less to more productive firms, as seems to be the case for the previously studied channels of adjustment (exit and contraction). This is indeed what I find: acquirers tend to be bigger, more profitable and more productive. In a final step, I look at the amount of inter-firm transfers of output and employment in North America that were due to M\&A during my sample period 1985-1997. Comparing results to resource transfers via exit and contraction, I find that M\&A was quantitatively important relative to these alternative channels of adjustment. Taken together, these results suggest that M\&A is an important alternative to the adjustment mechanisms of firm and establishment closure and contraction that have been emphasized in earlier research.

A number of recent theoretical contributions in International Trade have also studied firm-level reallocation processes triggered by trade liberalization (Melitz, 2003; Bernard et al., 2003; Bernard, Redding and Schott, 2004; and Falvey, Greenaway and Yu, 2004). Similar to the empirical literature on plant- and firm-level adjustment by which they were motivated, however, they do not examine M\&A as a form of resource transfer. Another group of papers in International Trade does look at M\&A but mostly in the form of crossborder transactions and in the context of foreign direct investment (e.g. Görg, 2000; Horn and Persson, 2001; Nocke and Yeaple, 2004; di Giovanni, 2005). Rather than analyzing 
M\&A as a means of industry restructuring, they examine its role as an alternative form of foreign market access in addition to greenfield investment and exports. Bertrand and Zitouna (2005) and Neary (2005) present models in which M\&A is a way of restructuring industries after trade liberalization, but they also restrict their analysis to cross-border mergers. In contrast, several theoretical contributions in Industrial Organization have directly focused on M\&A as a mechanism for transferring resources between domestic firms. In particular, Jovanovic and Rousseau $(2002,2004)$ use models with heterogenous firms to show how M\&A can serve as a complement to exit and internal adjustment to firm- and industry-specific shocks. However, they restrict their attention to closedeconomy settings and only analyze domestic shocks.

On the empirical side, contributions in Corporate Finance and Industrial Organization have since long pointed out that M\&A can play a substantial role in restructuring industries and that its consequences go far beyond a mere change in ownership (e.g. Jensen, 1993; Kaplan, 2000; Copeland et al., 2003). Specifically related to the question at hand, authors like Jovanovic and Rousseau (2002) or Andrade and Stafford (2004) have shown that M\&A is indeed frequently used as a way of firm expansion and complements or replaces internal investment in that respect. Comparisons of empirical studies also show that acquisitions perform very similarly to other forms of investment in terms of abnormal stock market returns (Andrade et al., 2001). On the target's side, takeovers usually bring large abnormal gains in share prices and most acquired assets show significant increases in productivity (Maksimovic and Phillips, 2001; Andrade et al., 2001). Finally, a number of recent studies have succeeded in directly linking increases in M\&A activity to domestic shocks like deregulation and financial innovation (Mitchell and Mulherin, 1996; Mulherin and Boone, 2000; Andrade and Stafford, 2004). The question of whether M\&A also plays a role in the industrial restructuring necessitated by trade liberalization shocks, however, has not yet been addressed in a rigorous way. While there is some descriptive and anecdotal evidence to the affirmative (Chudnovsky, 2000; OECD, 2001), no clear econometric results have been presented sofar. ${ }^{2}$ This is the gap the present contribution tries to fill.

The remainder of this paper is structured as follows. Section 2 presents a simple model of trade liberalization and resource transfer via M\&A. This section is intended to highlight the principal economic mechanisms at work and to give some guidance for the subsequent empirical analysis. Section 3 provides additional background information on CUSFTA

\footnotetext{
${ }^{2}$ An earlier study by Mitchell and Mulherin (1996) and a recent working paper by Greenaway et al. (2005) present (mixed) evidence on the link between import penetration rates and M\&A. However, since there is no exogenous variation in this measure of exposure to trade, it is not obvious whether their results can be interpreted in favor or against a link between trade liberalization and M\&A. For example, any negative productivity shock that triggers restructuring of a given industry is likely to involve M\&A (see Andrade et al., 2001). At the same time, the decline in the sector's relative productivity as compared to the rest of the world will lead to more imports and a higher import penetration rate. Such issues are reminiscent of the problems which plagued earlier studies on the link between trade and mark-ups, firm size or productivity (as discussed in Tybout, 2001, or Fernandes, 2003).
} 
and section 4 describes the data. Section 5 proceeds to an empirical investigation of changes in M\&A activity in the wake of CUSFTA, section 6 compares characteristics of targets and acquirers and section 7 provides evidence on the quantitative importance of $\mathrm{M} \& \mathrm{~A}$ as a form of resource transfer. I conclude with a summary of findings and directions for future research (section 8).

\section{Theoretical Framework}

How might trade liberalization lead to increases in M\&A activity? This section presents a simple model of M\&A as a means of resource transfer between firms in order to illustrate one potential mechanism. The model's underlying idea is that all firms possess assets that are of interest to other firms, like specific production skills, marketing capabilities or physical capital (in the following I will simply talk of capital). Changes in demand and supply conditions will lead to changes in firm-specific demand for these assets, with expanding firms wanting to increase their stocks and contracting firms looking for potential buyers. The M\&A market then provides a channel through which the necessary transfer can take place. Against this background, I study the effect of the demand shock arising from bilateral trade liberalizations such as CUSFTA. The crucial feature of this shock is its differential effect across firms with different levels of productivity. As a number of studies have shown, setting up export activities is costly and requires an initial investment (see Roberts and Tybout, 1997; Bernard and Jensen, 2004). Thus, only more productive firms that can afford these fixed costs will benefit from liberalization through increased exporting opportunities. Low productivity firms, in contrast, will suffer lower profits due to more intense product market competition from foreign firms while at the same time being unable to benefit from better access to the foreign market. ${ }^{3}$ Thus, while exporters need additional capital in order to expand operations, non-exporters attach less value to their existing capital stock. The presence of an M\&A market then allows the two parties to engage in a mutually beneficial transfer of capital.

The model presented below tries to capture this intuition in the simplest possible framework, building on the earlier contributions by Melitz (2003) and Jovanovic and Rousseau (2002). I analyze a setting with two symmetric countries in which M\&A is used to transfer capital between firms with different productivity levels. I start in an initial steady state equilibrium in which firms have already acquired the optimal capital stocks associated with the prevailing level of trade costs. I then shock this equilibrium by an unanticipated lowering of trade barriers which triggers a transfer of capital via M\&A from non-exporters to exporters (i.e. from less productive to more productive firms).

\footnotetext{
${ }^{3}$ This differential effect of bilateral trade liberalizations across firms is also analyzed in Melitz (2003).
} 


\subsection{Model Setup and Initial Equilibrium}

Following Melitz (2003), I analyze a setting with two symmetric countries, home and foreign. In each country, firms produce differentiated varieties under monopolistic competition. Constant per-period demand in the initial steady state is generated by standard CES preferences:

$$
u(q)=\left[\int_{\gamma \varepsilon \Gamma} q(\gamma)^{\frac{\sigma-1}{\sigma}} d \gamma\right]^{\frac{\sigma}{\sigma-1}}
$$

where $\Gamma$ is the set of varieties available (both domestically produced and imported) and $q(\gamma)$ is consumption of any given variety. Utility maximization by consumers yields demand $(q)$ and expenditure levels $(r)$ of any variety $\gamma$ as $q(\gamma)=p(\gamma)^{-\sigma} P^{\sigma-1} E$ and $r(\gamma)=p(\gamma)^{1-\sigma} P^{\sigma-1} E$. In these expressions, $p(\gamma)$ is the price of variety $\gamma, \sigma>1$ the elasticity of substitution between any two varieties and $P$ the CES price index defined as $P=\left[\int_{\gamma \varepsilon \Gamma} p(\gamma)^{1-\sigma} d \gamma\right]^{\frac{1}{1-\sigma}}$. Total expenditure $E$ consists of aggregate profits only which I normalize to one in the following.

Turning to the supply side, I assume for simplicity that varieties are produced using non-depreciating capital $(k)$ as the only factor of production. Firms are heterogenous in productivity levels $(\varphi)$ and the amount of capital required to produce a given amount of output $(q)$ is given by $k=\frac{q}{\varphi}+F$. This production function implies a minimum capital stock of $F$ which firms need to acquire in order to enter the market.

Both economies are endowed with a fixed capital stock of $K$ which is owned by firms. Capital is traded on an M\&A market at a price of $i /(1-\delta)$ where $\delta$ is the exogenously given and time-invariant discount factor (and $i$ is thus the amortized per-period cost of acquiring one unit of capital). Writing the M\&A price in this way facilitates the comparison of lifetime revenues and costs needed below for the firms' optimization problem. Capital acquired on the M\&A market takes on the acquirer's productivity $\varphi$ after acquisition but I assume that the target's variety cannot be used. ${ }^{4}$ Note that it would be straightforward to allow for internal investment or a market for used capital as additional channels through which firms can adjust their capital stocks. Since none of the principal findings would be changed by these extensions, however, I prefer to stick to the more tractable model outlined here. ${ }^{5}$

\footnotetext{
${ }^{4}$ The assumption that productivity is owner-specific is a standard way in the theoretical literature on M\&A to assure the profitability of mergers (e.g. Bjornvatn, 2004; Jovanovic and Rousseau, 2002). It is consistent with empirical observations for the U.S. that plant productivity increases after acquisitions by more productive owners and decreases if the acquirer's plants are less efficient on average (Maksimovic and Phillips, 2001). On the other hand, ruling out use of a target's variety eliminates incentives for the most productive firm to take over all remaining firms. Such a situation would certainly be inconsistent with empirical facts. It would also render meaningless any analysis of capital transfers via M\&A in response to external shocks.

${ }^{5}$ Internal investment could be introduced, for example, by allowing firms to employ labor from an additional sector to produce new capital. Distinguishing a market for used capital from the M\&A market would be possible by introducing variable costs for adapting capital for sale (see Jovanovic and Rousseau,
} 
As said, I consider an initial steady state equilibrium in which no firm has an incentive to exit or enter the market or change its capital stock level. First consider the determination of the optimal capital stock of active firms in this equilibrium. With every unit of capital firms hold in addition to $F$, they can generate per-period revenues of $p \varphi$ but face opportunity costs of $i /(1-\delta)$ since they could also offer their capital for sale on the M\&A market. Since every firm is a monopolist for its variety, it chooses a price-output combination that maximizes total discounted profits, given by $\pi_{T}(\varphi)=\frac{p q}{1-\delta}-\left(\frac{q}{\varphi}+F\right) \frac{i}{1-\delta}$. The optimal levels of prices and per-period output are thus $p(\varphi)=\frac{\sigma}{\sigma-1} \frac{i}{\varphi}$ and $q(\varphi)=\left[\frac{\sigma}{\sigma-1} \frac{i}{\varphi}\right]^{-\sigma} P^{\sigma-1}$, requiring a capital stock of $k_{d}(\varphi)=\left[\frac{\sigma}{\sigma-1} i\right]^{-\sigma} \varphi^{\sigma-1} P^{\sigma-1}+F$.

In addition to selling domestically, active firms can also export to the foreign market. However, they incur variable "iceberg"-type trade cost in doing so, i.e. for every unit they ship only $1 / \tau$ units arrive while the rest melts during transport. The corresponding export price is thus $p_{x}(\varphi)=\frac{\sigma}{\sigma-1} \frac{\tau i}{\varphi}$ and per-period exports are $q_{x}(\varphi)=\left[\frac{\sigma}{\sigma-1} \frac{\tau i}{\varphi}\right]^{-\sigma} P^{\sigma-1}$. In addition to incurring the variable trade costs measured by $\tau$, exporters also have to make a one-time capital investment of $F_{x}$ in order to serve the foreign market. Thus, total capital demand for export production is $k_{x}(\varphi)=\left[\frac{\sigma}{\sigma-1} i \tau\right]^{-\sigma} \varphi^{\sigma-1} P^{\sigma-1}+F_{x}$. Note that the investment $F_{x}$ is needed in addition to the domestic setup capital $F$ and can be thought of as adapting products to foreign standards, establishing local distribution networks etc. (see Roberts and Tybout, 1997).

Given active firms' optimal capital stocks, it remains to determine the set of active firms. In each market, there is a large number $\left(M_{e}\right)$ of potential entrants. Firm productivities are initially drawn at random from a cumulative distribution $V(\varphi)$ but all firms acquire knowledge about their productivity parameter $\varphi$ before entry, i.e. before acquiring the minimum capital amount $F$ or any additional capital. ${ }^{6}$ Thus, only those firms will produce for which the sum of discounted future operating profits given by $\frac{p q}{1-\delta}-\frac{q}{\varphi} \frac{i}{1-\delta}$ is at least equal to the setup costs $F i /(1-\delta)$. Similarly, only firms that can cover the fixed exporting cost $F_{x} i /(1-\delta)$ through future exporting profits will enter the export market. These two entry conditions can be used to obtain expressions for the threshold productivities at which production for the domestic and foreign market becomes profitable (denoted $\varphi^{*}$ and $\varphi_{x}^{*}$, respectively). Appendix A.1 provides the corresponding derivations and results but my interest here is on the resulting levels of capital

2002). These additional forms of adjustment would put upper and lower bounds on the M\&A price but would not eliminate resource transfers via $\mathrm{M} \& \mathrm{~A}$ in reaction to trade liberalization.

${ }^{6}$ Introducing uncertainty of potential entrants about their future productivity levels combined with an exogenous probability of firm death as in Melitz (2003) would allow generating continuous entry and exit of firms and steady state M\&A activity (in the sense that entrants with insufficient productivity would want to immediately resell their assets). However, the basic intuition of trade liberalization leading to a reshuffling of resources to more productive firms can equally well be captured in the simpler model presented here. 
demand for domestic and export production.

Demand for capital for domestic production $\left(k_{d}\right)$ comes from all firms with $\varphi \geq \varphi^{*}$ while firms with $\varphi \geq \varphi_{x}^{*}$ need additional capital $\left(k_{x}\right)$ to produce for the export market. To obtain explicit solutions for $\varphi^{*}, \varphi_{x}^{*}, k_{d}$, and $k_{x}$, I choose a specific distributional form for $V(\varphi)$. In line with other contributions in the heterogeneous firm literature (e.g. Melitz and Ottaviano, 2005), I let $\varphi$ be Pareto-distributed, i.e. with cumulative density $V(\varphi)=1-\left(\frac{\kappa}{\varphi}\right)^{a}$, where $\kappa>0, a>\sigma-1>0$, and $\varphi \geq \kappa$. With these assumptions, I can determine the market clearing price $i /(1-\delta)$ and derive total capital stocks used for exporting and domestic production (see appendix A.2 for details):

$$
K_{d}=\int_{\varphi=\varphi^{*}}^{\infty} k_{d}(\varphi) M_{e} v(\varphi) d \varphi=K\left[1+\tau^{-a}\left(\frac{F_{x}}{F}\right)^{\frac{\sigma-1-a}{\sigma-1}}\right]^{-1}
$$

and

$$
K_{x}=\int_{\varphi=\varphi_{x}^{*}}^{\infty} k_{x}(\varphi) M_{e} v(\varphi) d \varphi=K\left[1+\tau^{a}\left(\frac{F_{x}}{F}\right)^{-\frac{\sigma-1-a}{\sigma-1}}\right]^{-1}
$$

where $\frac{\sigma-1-a}{\sigma-1}<0$ since by assumption $a>\sigma-1>0$.

\subsection{Bilateral Trade Liberalization}

Now consider an unanticipated decline in variable trade costs $\tau$. Similar to Melitz (2003), I focus on a comparison of the old and the new steady state equilibrium and in particular on the changes in capital allocation between the two equilibria. It is clear from (1) and (2) that the amount of capital used for domestic and export production will be different in the new equilibrium, with $K_{x}$ increasing and $K_{d}$ decreasing. Intuitively, increased presence of foreign exporters will lower revenues for local firms from production for the domestic market, implying lower returns to a firm's existing capital stock. Consequently, import competing firms offer part of their capital stock for sale on the M\&A market and any firm with $\varphi$ below the new entry threshold $\varphi^{*}$ will use M\&A to exit the market altogether. While trade liberalization thus leads to an increase of supply in M\&A capital, it also increases capital demand for export production. This is since lower costs for accessing the foreign market imply larger market shares for exporters who in turn demand additional capital. Better access to foreign markets also lowers the minimum productivity level required for profitable exporting $\left(\varphi_{x}^{*}\right)$, leading to an increase in the number of exporters.

Since the total capital stock per country is fixed at $K$, any increase in export capital demand is offset by an equal decrease in capital demand for domestic production. Thus, the total amount of reallocation of capital into export production can be determined by differentiating either of expressions (1) or (2) with respect to $\tau$. Opting for (1), I obtain: 


$$
d K_{d}=\frac{a \lambda K}{[1+\lambda]^{2} \tau} d \tau>0
$$

where I defined $\lambda=\tau^{-a}\left(\frac{F_{x}}{F}\right)^{\frac{\sigma-1-a}{\sigma-1}}>0$ as an overall measure of initial trade costs. The total amount of capital transfers is simply the absolute value of this derivative, i.e. $T=\left|d K_{d}\right|$. Since $a, K, \lambda$ and $\tau$ are all positive, $T$ can be written as:

$$
T=\frac{a \lambda K}{[1+\lambda]^{2} \tau}|d \tau|
$$

That is, the amount of resource transfer via M\&A is increasing in the magnitude of trade liberalization (as captured by $|d \tau|) .{ }^{7}$ Also note that capital is channelled from non-exporters to exporters. Since the presence of fixed exporting costs means that only the most productive among the active firms will export, the transfer of capital is in effect from less to more productive firms (see appendix A.1 for a formal derivation). Finally, note that revenues $(r)$ and per-period profits net of capital costs (that is, $(1-\delta) \pi_{T}$ ) are increasing functions of productivity $\varphi$ in this model. This implies that acquiring firms are also larger (in terms of sales) and more profitable than targets.

\subsection{Extensions and Questions for the Empirical Analysis}

Although the model just presented is highly stylized, its central intuition holds much more generally: trade liberalization has asymmetric effects across firms which in turn necessitates a redistribution of resources via M\&A. In the within-industry setting analyzed here, this leads to the prediction that decreases in bilateral trade barriers lead to a transfer of resources from import-competing firms to new and existing exporters. While a within-sector analysis will be part of the empirics, it is however useful to be aware of whether and how the theoretical results would have to be modified in a more general setting.

First, while the model assumes two symmetric trading partners, the U.S. market is about ten times the size of the Canadian market. This suggests that trade liberalization should have a much stronger effect on M\&A activity in Canada since increases in both import competition and exporting opportunities will be substantially bigger there. ${ }^{8}$

\footnotetext{
${ }^{7}$ Note that interpreting the whole of $T$ as M\&A assumes that the export and domestic production unit of a firm sell or acquire all of their capital through the M\&A market. Alternatively, one could assume that exporters reallocate capital internally from domestic to export production and acquire only the shortfall on the M\&A market. While this assumption considerably complicates the analysis, the principal results on which I will rely for my empirical analysis will remain unchanged: M\&A is increasing in $|d \tau|$ and $|d \tau|$ enters the reallocation volume $T$ multiplicatively (results available from author upon request).

${ }^{8}$ This intuition can be formalized by extending the above model to asymmetric countries (requiring a freely tradable numeraire good to fix the price of capital and to allow the derivation of closed form solutions). Results available from the author upon request.
} 
Second, extending the model to multiple sectors raises the possibility of diversifying or conglomerate M\&A transactions that go across industry boundaries. The basic intuition of the model will still apply, however: firms want to acquire production capacity in other industries through acquisitions both because of improved exporting opportunities there or because increased import competition has made assets cheaper. Since the target's capital is likely to be sector specific in the vast majority of cases, this argument also makes clear that the relevant reductions in variable trade costs in such a multi-sector model are the ones facing the acquisition target. This is because the acquirer will have to use the new production capacity to produce the target industry's goods. ${ }^{9}$

Finally, acquisitions might also be cross-border in nature, e.g. expanding foreign exporters may want to acquire import competing domestic firms. While the decrease in the latter firms' reservation price for their assets will encourage acquisitions, there will also be a counterbalancing effect for horizontal M\&A arising from tariff-jumping considerations: decreases in variable trade costs make it easier to serve the foreign market via exports and thus reduce the incentives to establish production capacity there via acquisitions. ${ }^{10}$

The second key implication that arose from the theoretical model was that resource transfers will be from less to more productive firms (since exporters are more productive than non-exporters). Again, a similar prediction should hold for acquisitions across both national and industry borders since M\&A will only create value for the buyer if the acquired assets can be put to a more profitable use. The productivity advantage of the acquiring firm and the ensuing selection into exporter status is what allows this increase in profitability in my model.

To summarize, the model and the above discussion suggest addressing the following questions in the empirical analysis:

1. Do reductions in variable trade costs (tariff cuts) lead to more takeovers of firms in the affected sector? Is this effect stronger in industries with larger tariff cuts (as predicted by equation 3$)$ ?

2. Is the effect similar for within- and cross-industry acquisitions? Is it similar for domestic and cross-border transactions? Is there a stronger impact on the M\&A activity in the smaller Canadian market?

\footnotetext{
${ }^{9}$ An easy way of formalizing this intuition would be in a two sector model in which firms can use production capacity in the other sector at their own productivity level $\varphi$ but first have to make an investment $I$ to acquire the necessary sector-specific production know-how (this would be addition to $F)$. If the productivity of an acquirer from the non-liberalizing sector is high enough to be an exporter in the liberalizing sector, a lowering of trade costs might raise its potential profits above the threshold $I$ and trigger entry.

${ }^{10}$ Both Bertrand and Zitouna (2005) and Bjornvatn (2004) formalize this trade-off between declining reservation prices of potential targets and better export access to the foreign market.
} 
3. Are acquirers more profitable and more productive than targets? Again, does this effect vary across the different M\&A categories (within- vs. between-industry and domestic- vs. cross-border)?

Answers to these questions will shed light on the qualitative characteristics of M\&A as an adjustment mechanism in the face of trade liberalization. A further interesting question that arises is whether resource transfers via M\&A are also quantitatively important. While the nature of my dataset does not allow a definitive answer to this question, I will provide some evidence that the overall amount of transfers is indeed likely to be large (section 7).

\section{The Case of CUSFTA}

The particular liberalization episode I will use for my empirical investigation is the Canada-United States Free Trade Agreements (CUSFTA) of 1989. The idea of abolishing trade barriers between Canada and the U.S. had been around for some time before CUSFTA but strong opposition in Canada had led to the eventual failure of all prior attempts at implementing free trade. Against this background and again against substantial political opposition, negotiations for CUSFTA started in May 1986, were finalized in October 1987 and the treaty was signed in early 1988. The agreement came into effect on 1 January 1989 which was also the date of the first round of tariff cuts. Tariffs were then phased out over a period of up to ten years with some industries eventually opting for a swifter phase-out.

In terms of economic analysis, CUSFTA presents several advantages over other trade liberalizations. First, the main instrument of liberalization - tariff cuts - is easily quantifiable and shows a large variation across sectors which allows for the implementation of a difference-in-differences estimation strategy. Secondly, CUSFTA was a clearly defined policy experiment in the sense that it was neither part of a larger packet of market reforms nor was it introduced in response to a macroeconomic shock, two factors that have made the identification of trade reform effects extremely difficult in other settings (Rodriguez and Rodrik, 2001; Trefler, 2004). In this sense, the reductions in tariff rates triggered by CUSFTA can to a large extent be regarded as exogenous - indeed, Trefler (2004) performs formal statistical tests for a wide range of specifications and dependent variables but finds little evidence to the contrary.

In the context of studying the impact of trade liberalization on M\&A, CUSFTA has two additional advantages. First, it was largely unanticipated since its ratification by the Canadian parliament was considered highly unlikely as late as November $1988 .^{11}$

\footnotetext{
${ }^{11}$ See Morck et al. (1998) for a chronology of the events leading up to the eventual ratification of CUSFTA. During the entire process, ratification was considered unlikely given both the prior history
} 
The fact that its eventual implementation thus came very much as a surprise to all participants considerably reduces concerns about anticipatory M\&A activity and makes the years before 1989 a suitable control period. In addition, CUSFTA was a liberalization agreement between industrialized countries with developed financial markets and few restrictions on mergers and acquisitions, at least in comparison to most other developing and developed countries. Indeed, although there exists, to my knowledge, no econometric evidence to date, there is some anecdotal evidence that CUSFTA has led to an increase in M\&A activity (OECD, 2001). Given that a number of existing studies have shown that there has also been a substantial impact on economic variables other than M\&A activity (e.g. Trefler, 2004, on productivity and employment; or Head and Ries, 1999, on plant scale and number of plants), it does thus not seem unreasonable a priori to expect an effect of CUSFTA on the acquisition behavior of firms.

\section{Data and Descriptive Statistics}

In line with existing studies, my empirical analysis of CUSFTA's impact on M\&A activity focuses on the manufacturing sector which still represents the bulk of tradable goods in an economy and is thus the sector most directly affected by trade liberalization. The time frame for my analysis is 1985-1997, the period for which I have data on tariffs, M\&A activity and firm-level characteristics of targets and acquirers.

Tariffs and M\&A Activity. I use annual three-digit U.S. and Canadian tariff data (140 industries) as my measure of the extent of trade liberalization. ${ }^{12}$ While CUSFTA also included provisions on non-tariff barriers, reductions of tariffs were the main instrument of liberalization. As has been pointed out among others by Trefler (2004) and Topalova (2004), tariff cuts also have the advantage of being a direct policy instrument and are as such less susceptible to endogeneity problems. This is in contrast to other more indirect measures like import penetration rates which are the result of a complex interaction process with a large number of additional factors. ${ }^{13}$

of failed ratifications of already negotiated free trade agreements with the U.S. and the strength of the opposition to CUSFTA. Indeed, John Turner, the opposition leader and a strong opponent of free trade with the U.S., publicly vowed as late as October 1988 that he would dismantle CUSFTA in case of victory in national elections scheduled for November 1988. Since his Liberal Party had a lead of at least $10 \%$ in opinion polls until right before the election, ratification did indeed seem unlikely. However, against all odds, the Canadian Conservative Party emerged as the surprise election winner and the government was returned with a parliamentary majority sufficient to ratify CUSFTA.

${ }^{12}$ The data are the same as those described in Head and Ries (1999). I would like to thank Keith Head for making them available to me. Appendix B provides some additional details on their construction.

${ }^{13}$ Compare footnote 2 and Rodriguez and Rodrik (2001) for a more general discussion of the pitfalls of various other indirect measures. Of course, tariff rates are at the discretion of policy makers and as such subject to different endogeneity problems. However, as argued in the previous section, such concerns have less weight in the case of CUSFTA where tariff cuts were unexpected and largely exogenous (at least once one controls for the variation in initial tariff levels - as I will do by using industry fixed effect, see below). 
Data on M\&A activity in the manufacturing sector comes from Thomson Financial's Worldwide M\&A database. The principal sources of information used by Thomson are over 200 English and foreign language news sources, SEC filings and their international counterparts, trade publications and proprietary surveys of investment banks, law firms and other advisors. The database includes all corporate transactions involving at least $5 \%$ ownership of a company and a transaction value of one million USD or more or where the value of the transaction is undisclosed. In line with the discussion in the previous sections, I use all M\&A deals involving acquisitions of U.S. or Canadian manufacturing targets by other U.S. or Canadian firms, yielding approximately 23,500 transactions in the period under study (1985-1997). I define "M\&A" broadly to include sales of individual business segments and divisions as well as of entire companies. This is consistent with the idea from the theoretical model that M\&A can both be a form of contraction and total firm exit. I further consider acquisitions of both majority and minority interests since there is strong evidence that significant influence for the acquirer is already given at participation rates well below 50\%. ${ }^{14}$ Transactions are classified into three-digit industries and matched with the tariff data according to the primary activity of the target company or the acquired business segment (see appendix B for details). For the purpose of this study, I will use the number of mergers and acquisitions in a given period as my principal indicator for M\&A activity. Using numbers rather then aggregate deal volumes has two principal advantages. First, it is the much more readily available indicator since for the majority of deals, transaction values are not published (this is the case for $55 \%$ of deals in my dataset). Second, value measures are extremely sensitive to the treatment of very large deals which often make up significant proportions of the total deal volume despite representing only a few out of several thousand transactions every year. In my sample, for instance, the three biggest deals on average make up about $20 \%$ of the aggregate deal volume in a given year. Within three-digit industries (the aggregation level of my empirical analysis), the biggest transaction alone accounts on average for over $30 \%$ of the entire industry volume during $1985-1997 .^{15}$

Tables 1 and 2 provide some descriptive statistics on M\&A activity and manufacturing

\footnotetext{
${ }^{14}$ Morck et al. (1998) cite evidence that the threshold for effective control lies on average at about $20 \%$ in the U.S. Similarly, the Canadian Competition Bureau (2002) considers all acquisitions of more than $10 \%$ of control rights as potentially anti-competitive, with the corresponding figure for the U.S. being $15 \%$ (Brealey and Myers, 2000, chapter 33). In any case, minority acquisitions comprise only about $12 \%$ of transactions in my sample. See section 5 for robustness checks excluding this category.

${ }^{15}$ Robustness checks using value data despite these problems yield qualitatively similar results for domestic Canadian M\&A activity as the count data estimates presented below (a "raw" regression with neither imputation of missing transaction values nor deletion of outliers yields an estimated perpercentage point effect of tariff cuts on M\&A activity of $14.6 \%$ - compared to $8.3 \%$ for the count results). For domestic U.S. transactions, these raw regressions yield a negative coefficient on tariff cuts but this can be linked to just two to three massive outliers (in particular, the 20 billion USD acquisition of RJR Nabisco by Kohlberg, Kravis and Roberts in 1988). In any case, the qualitative picture that will emerge later on - a strong impact of CUSFTA on domestic Canadian M\&A activity and a mostly insignificant one on the U.S. and cross-border categories - stays intact in these value regressions.
} 
tariffs in North America over the period 1985-1997. I start with an analysis of target firms. The first four columns of table 1 show the number of M\&A transactions in the U.S. and Canada at the two-digit level of the U.S. Industrial Classification of 1987. As seen, domestic M\&A activity (columns 1 and 4) is more common than cross-border transactions (columns 2 and 3), even for the smaller Canadian market. Looking across industries, it becomes apparent that there is substantial variation in the number of deals. One simple reason for this is probably that different industries have very different numbers of firms and establishments and thus more or less "potential" for takeovers. Sectors with more players usually also have lower concentration ratios and face less scrutiny by antitrust authorities. Columns 5-6 which list the average number of establishments per industry confirm these conjectures: industries with more establishments have more M\&A activity - the correlation coefficient between the number of establishments and total M\&A transactions is $+52 \%$ for the U.S. and $+55 \%$ for Canada. ${ }^{16}$ More subtly, there also seems to be a connection between M\&A activity and initial tariff rates (columns 7-8): industries with higher import tariffs in 1988 also experience less takeovers during the entire period 1985-1997 (the correlation coefficient is $-32 \%$ for the U.S. and $-48 \%$ for Canada). This seems in part to be a direct consequence of the relation between M\&A activity and the number of establishments: highly protected industries are usually industries in decline which already have experienced shakeouts and have relatively few remaining players.

The next question is who the buyers of U.S. and Canadian manufacturing firms are. Table 2 provides some information on this by listing the principal field of activity of acquiring firms. As the figures show, roughly $70 \%$ of acquirers are also manufacturing firms, both in the U.S. and in Canada. Moreover, about 35\% of transactions occur within the same three-digit sector and another $13 \%$ within the same two-digit sector, so that within-industry reallocation via M\&A seems to be an important phenomenon. Around $17 \%$ of acquirers of U.S.-firms (21\% for Canada) have their principal field of activity outside manufacturing (SIC-codes 2-3), although this figure probably overestimates the incidence of diversifying or conglomerate M\&A. This is since about one quarter of nonmanufacturing acquirers actually possess secondary fields of activity in manufacturing, with the figure being as high as $50 \%$ in some categories (see columns 3 and 7 ). ${ }^{17}$

The second to last line of table 2 lists a category of acquirers that deserves special attention. The group "Investors, n.e.c." (SIC 6799) represents an amalgamation of dif-

\footnotetext{
${ }^{16}$ The sources for the number of establishments are the U.S. Census Bureau and Statistics Canada. I use the number of establishments rather than the number of firms since my definition of M\&A includes both acquisition of entire firms and of individual subdivisions and possibly plants.

${ }^{17}$ Looking at secondary fields of activity also increases the numbers of transactions that are potentially of within-industry nature. Columns 4 and 8 show the fraction of acquirers that have at least one manufacturing 3-digit SIC code that matches the primary or any secondary manufacturing SIC code of the target. If one counts all these transactions as intra-industry, the share of this reallocation type rises to $40 \%$ which represents only a modest increase of about 5\%-points. Since this is clearly an upper bound, classification according to primary fields of activity seems to be a good approximation in determining the within- or between-industry nature of M\&A.
} 
ferent types of acquirers that are not easily classifiable elsewhere. The main subgroups of SIC 6799 are private equity and venture capital firms, investor groups, and individual investors. In all cases, it seems likely that acquisition by these groups represents a significant reallocation of resources in the sense that targets will be exposed to substantial changes in management practices, restructuring etc. Also, among investor groups, alliances of different manufacturing firms are not uncommon so that part of SIC 6799 are indeed within-manufacturing acquisitions. For these reasons, I keep transactions involving SIC 6799 as part of my sample though I will present robustness checks excluding this category.

Target and Acquirer Characteristics. For the comparison of target and acquirer characteristics in section 6, I match the transaction parties from the Thomson M\&A database to Compustat North America and Compustat Global using the CNUM-identifier common to both datasets. Thomson Financial itself also provides financial data on a small number of targets and acquirers which I use to complement the information from Compustat. My indicators of firm performance will be net sales, pre-tax income, the number of employees, net capital stocks, and productivity and profitability measures based on these variables. ${ }^{18}$ The four indicators net sales, income, employees and net capital stocks are available for between 7,500 to 12,500 out of the 47,000 company-year combinations in my data (some companies are involved in several transactions in the sample period).

The use of Compustat implies that my sample for comparing target and acquirer characteristics consists mainly of publicly traded firms (although about $5 \%$ of firms are privately held). I believe that this does not pose major problems for the analysis. First, publicly traded firms make up a substantial fraction of the full sample of transaction parties used to analyze changes in M\&A activity (about 35\%, with private companies and firm subsidiaries making up the remaining $65 \%$ in the Thomson M\&A database). Second, as I will show in the next section, the impact of CUSFTA on publicly traded firms was if anything slightly stronger than for the full sample of firms. Third, although the number of publicly traded firms is small relative to the overall number of companies in Canada and the U.S., their overall share of output and employment is above $80 \%{ }^{19}$ Thus, even if target-acquirer differences for non-publicly traded firms were very different, the findings presented in section 6 would still have strong economic relevance.

\footnotetext{
${ }^{18}$ The exact sources for Compustat North America are data items 12 and 117 (net sales), 122 and 170 (pretax income), 29 and 146 (employees), and 8 and 141 ("net property, plants and equipment", used as proxy for net capital stocks). For Compustat Global, data are contained in items 1 (net sales), 21 (pretax income), 162 (employees), and 76 ("net tangible fixed assets", used as proxy for net capital stocks). I use 4-digit sectoral deflators to convert nominal values to 1987 values. I then convert entries in Canadian dollars to US dollars by using the exchange rate for the base year 1987.

${ }^{19}$ This figure is based on a comparison of aggregate production and employment in Compustat North America and Compustat Global with comparable data from the UNIDO database.
} 
Quantitative Importance of M\&A: For the comparison of the amount of firmlevel resource transfers via M\&A, contraction and exit (section 7), I will again rely on information for publicly traded firms from Compustat Global and Compustat North America. In addition to data on output (net sales) and employment, I use information on the reason for deletion of companies from the Compustat files. ${ }^{20}$ I include all manufacturing firms listed as active in either Compustat North America or Compustat Global at some point during the period 1985-1997. After dropping some smaller Canadian firms for which no exit information is available, this yields a sample of 331 Canadian and 5827 U.S. firms which again represent over $80 \%$ of manufacturing output and employment in North America.

\section{Trade Liberalization and M\&A}

\subsection{A First Look at the Figures}

How has M\&A activity in North America evolved over time and what was the impact of CUSFTA? Figure 1) plots the number of yearly manufacturing M\&A transactions over the period 1985-1997 for four different categories, all expressed as indices relative to 1988: domestic U.S. transactions, domestic Canadian transactions, acquisitions of U.S. firms by Canadian firms and acquisitions of Canadian firms by U.S. firms. The graphs also indicate the start date of CUSFTA (1 January 1989) by a vertical line and have linear splines fitted to the data points pre- and post CUSFTA.

The figures do not reveal any clear effect for both U.S. domestic activity and CanadaU.S. takeovers. Takeovers of Canadian firms, however, both by other Canadian and U.S. firms, show a marked increase in 1989, the first year after the implementation of CUSFTA. At the same time, all graphs display a general strong upward trend in the number of M\&A deals over the entire period. This provides some first evidence on the problems of descriptive studies that comment on M\&A activity in the wake of CUSFTA (such as OECD, 2001): the strong increases in transactions in the 1990s might simply reflect an underlying long-run trend. The before-after comparisons undertaken here do not have this problem although it could still be that changes around 1989 were due to other economy-wide factors contemporaneous to the first round of tariff cuts (for example, CUSFTA also contained a general liberalization agreement on cross-border capital flows).

To provide stronger evidence that the observed changes in M\&A activity are indeed due to the tariff cuts implemented through CUSFTA, I thus split transactions within each of the four categories into two groups (figure 2). Those from the $50 \%$ of target

\footnotetext{
${ }^{20}$ The relevant Compustat North America data items are 12 and 117 (net sales) and 29 and 146 (employees). Date and reason for deletion are provided in data footnotes AFTNT33-AFTNT35. For Compustat Global, sales and employee data are contained in items 1 and 162, and reason and date of deletion in the variables INCO and INCOD.
} 
industries that faced the steepest tariff cuts and those from the remaining 50\%. I choose tariffs levied by the target's country for this classification. In practice, U.S. and Canadian tariff cuts are very highly correlated so that results are similar when using the other tariff measure. From these figures, a slightly different picture emerges. For the two domestic categories, the index of M\&A activity is very similar across the two groups in the preCUSFTA period. From 1989 onwards, however, M\&A activity in Canada increases by substantially more in the most affected group. For the U.S., there is also a slightly more pronounced increase for this group although the difference to the least affected group is much smaller than in Canada. It thus seems that the impression from the initial graphs holds up to this difference-in-differences analysis. M\&A activity in Canada rose sharply after 1989 and the magnitude of this increase seems to be related to the extent of tariff cuts across sectors. The impact on the U.S. is much smaller, consistent with the notion that the liberalization shock was substantially bigger in Canada which integrated with a market ten times her own size.

Turning to the cross-border categories (the two right hand side panels), the graphs show slightly more volatility than in domestic M\&A activity, reflecting in part the smaller number of transactions across the U.S.-Canadian border. Still, it seems that effects on cross-border M\&A went in opposite directions. While Canadian acquisition activity in the U.S. shows a slightly stronger increase in the group of most affected industries, the opposite holds true for takeovers of Canadian by U.S. firms. This last finding is consistent with tariff-jumping motives as an additional determinant for horizontal crossborder M\&A transactions. That is, in industries with stronger Canadian tariff cuts, U.S. firms were less dependent on acquiring local production capacity to serve the Canadian market. Increasing returns to scale may have reinforced this trend by inducing U.S. firms to concentrate production in their larger domestic market. Such a home-market-type effect may also explain the stronger increases in Canadian acquisitions in the U.S. in the most-affected group, which took place despite easier export access to this market. ${ }^{21}$

\subsection{Econometric Specification and Baseline Results}

This section evaluates whether the impressions from the graphs of the last section carry over to a formal econometric analysis. Among other things, the results obtained so far have drawn attention to two potential pitfalls such an analysis faces. First, M\&A activity shows strong inter-industry variation and is negatively related to initial tariff levels (see section 4). Since all tariffs were eventually eliminated under CUSFTA, higher initial levels also meant stronger subsequent cuts, implying a potentially spurious correlation of tariff

\footnotetext{
${ }^{21}$ An often cited example that fits these explanations is the earlier North American Autopact of 1964 which liberalized automotive trade between Canada and the U.S.: no longer facing prohibitive tariffs, U.S. firms were able to concentrate production in their larger home market and serve the Canadian market through exports rather than through local production.
} 
changes and M\&A activity. Second, the strong increase in the number of mergers and acquisitions over the whole period 1985-1997 suggests the presence of a general economywide trend in M\&A activity. Since all tariffs came down after 1989 this could again lead to a spurious correlation with tariff cuts. To address these issues, I will implement a difference-in-differences approach by controlling for both industry and time fixed effects.

To obtain guidance on the choice of an appropriate econometric specification, I turn to the theoretical model derived earlier. There, the volume of capital reallocation was given by $T=\frac{a \lambda K}{[1+\lambda]^{2} \tau}|d \tau|$ (equation 3), where $|d \tau|$ was the absolute change in variable trade costs, $K$ an economy's capital stock, $\lambda$ a measure of initial trade costs (both fixed and variable), and $a>0$ the Pareto-distribution's shape parameter.

First consider the choice of empirical proxies for $|d \tau|$ and $T$. In the model, variable trade $\operatorname{costs} \tau$ are of the iceberg-type and thus relate to tariffs $t$ as $\tau=1+t$ which implies $d \tau=d t$. My measure for $|d \tau|=|d t|$ will thus be the absolute change in tariffs from the pre-CUSFTA year of 1988 to the last year for which I have tariff data (1997). As $d t \leq 0$ for all sectors, this absolute change is $|d t|=-d t=$ tariff $_{1988^{-}}$tariff $_{1997}$. Because CUSFTA was a bilateral liberalization agreement and the treaty partners tended to protect the same sectors, the magnitude of U.S. and Canadian tariff cuts is very similar across industries. In line with previous empirical studies of trade liberalizations - which mostly look at unilateral tariff reductions by a particular country - I opt for domestic tariffs. That is, I use Canadian tariff cuts when analyzing the impact of CUSFTA on takeovers of Canadian firms and U.S. tariffs cuts for transactions involving U.S. targets. ${ }^{22}$ As already mentioned, my proxy for the amount of reallocation via $M \& A(T)$ is the number of transactions which I denote MA. In order to smooth the data and reduce the number of zero observations, I aggregate numbers over the pre- and post CUSFTA-period (1985-1988 and 1989-1997). This yields a panel with two time periods and 140 industries. With these choices of proxies for $|d \tau|$ and $T$, I can write my specification as:

$$
M A=\frac{a \lambda K}{[1+\lambda]^{2} \tau}|d t|
$$

Given the multiplicative form of (4), one possibility would be log-linearization and estimation via OLS. However since the occurrence of zeros in MA is still frequent, in particular for the cross-border merger categories, such an approach is not feasible. Also note that MA is a non-negative and usually small integer, suggesting that count data models are a more appropriate choice here. To obtain a corresponding specification, I rewrite the right-hand side of (4) in exponential form:

\footnotetext{
${ }^{22}$ Robustness checks using foreign tariff reductions as regressors yielded similar results which is unsurprising given the very high correlation of tariff cuts (in excess of 80\%). An interesting area for future work would be to study more asymmetric liberalization agreements with sufficient independent variation in tariff cuts. Such agreements would allow to separately identify the effects of import- and export-promoting policies on M\&A activity.
} 


$$
M A=\exp \left(\ln a+\ln K+\ln \frac{\lambda}{[1+\lambda]^{2} \tau}+\ln |d t|\right)
$$

The identifying assumption I will initially make (but later relax) is that the various components of (5) besides $|d t|$ are either time- or industry invariant and can thus be captured by time- and industry fixed effects, $d_{i}, d_{\text {pre }}$ and $d_{\text {post }}$ (where $d_{\text {pre }}$ and $d_{\text {post }}$ denote the pre- and post CUSFTA period, respectively). ${ }^{23}$ Writing (5) in expectations form and using the dummy variables just defined then yields a conditional mean exactly identical to the one found in fixed effect count data models: ${ }^{24}$

$$
E\left(M A_{i t} \mid d t, d_{i}, d_{t}\right)=\mu_{i t}=\exp \left(d_{i}+d_{\text {pre }}+d_{\text {post }}+\beta \times d_{\text {post }} \ln |d t|_{i t}\right)
$$

Consistent estimates of the parameters in (6) can be easily obtained via fixed effects Poisson estimation. I opt for Poisson rather than a negative binomial model since the former has the desirable robustness property that consistency of estimates will be achieved as long as the conditional mean (6) is correctly specified - irrespective of whether $\mathrm{MA}_{i t}$ actually follows a Poisson distribution (see Wooldridge, 1999 and 2002; Santos Silva and Tenreyro, 2004). Standard errors will be affected by deviations from the Poisson assumption but computation of variance-covariance matrices robust to overdispersion, heteroskedasticity and within-group correlation is straightforward (Wooldridge, 1999 and 2002).

Table 3 reports results for my baseline Poisson fixed effects model (6) for the full sample of acquirers, i.e. manufacturing firms from the same three-digit sector as the target, manufacturing firms from other sectors and firms with principal activities outside manufacturing. Line 1 shows coefficient estimates of $\beta$ and $d_{\text {post }}$ for each of the four subgroups of M\&A (domestic and cross-border transactions). ${ }^{25}$ As seen, the strongest impact of CUSFTA seems to be on domestic Canadian M\&A activity which is consistent with the earlier graphical analysis. As an approximation, the coefficient estimates suggests that

\footnotetext{
${ }^{23}$ Since the parameter $a$, initial trade barriers $\lambda$, and countries' capital stocks $K$ are all constant in the model, this identifying assumption is consistent with the earlier theory. Obviously, various industry-level shocks might cause time-industry-variation in $a$ or $K$, a point which I discuss in more detail below and try to control for.

${ }^{24}$ Note that the below specification implicitly sets tariff cuts in 1985-1988 to zero. This is necessary since my data sources do not contain US tariffs for 1985 and 1986 and only imputed data for Canada (see appendix B). However, as shown for example in $\mathrm{Gu}$ et al. (2003) and also evident in my Canadian tariff data, tariff changes in 1985-1988 were very small both in absolute terms and compared to the subsequent cuts. Thus, assuming a zero-change seems to be a good approximation (also see appendix B for a brief discussion of the very similar results obtained by using the imputed Canadian data).

${ }^{25} d_{\text {pre }}$ is the excluded category so that $d_{\text {post }}$ gives the average relative increase of M\&A activity in comparison to the pre-CUSFTA period that is not explained by tariff cuts. Note that contrary to what is sometimes asserted in the literature, there is no incidental parameter problem with the fixed effects Poisson regressions (see Cameron and Trivedi (1998) for a proof). That is, conditional maximum likelihood estimation (using total industry transactions $M A_{i}=\sum_{t} M A_{i t}$ as the sufficient statistic) yields identical results to simple QML Poisson estimation with a set of industry dummies.
} 
each doubling of tariff cuts in a given target industry led to an increase of $36.5 \%$ in the number of domestic Canadian M\&A transactions. Results are also significantly positive for U.S. domestic M\&A activity, although the magnitude of the coefficient estimate is only about $1 / 5$ of its Canadian counterpart.

Lines 2-3 of table 3 show results for two alternative measures of tariff cuts. The first measure uses absolute changes in tariffs, i.e. $d_{\text {post }} \times\left(\right.$ tariff $_{1988}-$ tariff $\left._{1997}\right)$ rather than $d_{\text {post }} \times \log \left(\right.$ tariff $_{1988}-$ tariff $\left._{1997}\right)$. This gives equal weight to each percentage point of tariff cuts, irrespective of the overall magnitude of the reduction. The second measure is a binary indicator taking the value one if an industry is among the $50 \%$ of industries with the highest tariff cuts, i.e. $d_{\text {post }} \times 1\left(d t>d t_{50 \%}\right)$. This measure is thus similar to the one used in the graphic analysis from the last section. The results from these two alternative measures show a qualitatively similar picture to the baseline estimates for domestic M\&A activity, i.e. the impact on Canada seems to have been much stronger. ${ }^{26}$ The coefficient estimates for the absolute change in tariffs - which is the most straightforward of all measures in terms of interpretation - indicate that for every percentage point decrease in tariffs the number of takeovers of firms in the affected industries increased on average by 8.3\%. Given that the mean decline in Canadian tariffs at the three-digit level was about $8 \%$, this suggests that CUSFTA increased M\&A activity by approximately $65 \%$. The corresponding coefficient for the U.S. is much lower (0.98) but still marginally statistically significant. This again highlights the differential impact of CUSFTA on the two markets, in particular if one takes into account that the mean U.S. tariff decline was only about $4 \%$ (yielding an estimated average impact on M\&A activity of just 4\%). Taking into account all three tariff cut measures, the picture is less clear for the cross-border merger categories since coefficients are mostly statistically insignificant. Qualitatively, however, the estimates give a similar impression as the earlier graphs: Canadian acquisitions in the U.S. have gone up as a result of tariff cuts while U.S. acquisitions in Canada have come down.

\subsection{Robustness Checks}

Control Variables I have so far relied on the assumption that tariff cuts were the only time- and industry-varying determinants of M\&A activity, which allowed me to identify the effect of CUSFTA from a simple difference-in-differences approach without additional controls. While M\&A activity will in practice also be influenced by other time-industry varying factors, one has to proceed carefully when choosing appropriate control variables. First, I will refrain from using a number of obvious industry-level

\footnotetext{
${ }^{26}$ Note that according to standard model selection criteria for maximum likelihood models (e.g. pseudo$\mathrm{R}^{2} \mathrm{~s}$ ) the theory-based based measure (log tariff changes) actually provides a marginally better fit than the two adhoc-measures. For the three baseline specifications estimated here, the results for the pseudo-R2s are: 0.87 (log changes), 0.86 (absolute changes), and 0.85 (binary measure).
} 
variables like employment, output, the number of firms or productivity growth. Besides likely endogeneity problems, the common concern with these variables is that there is ample evidence that they are themselves strongly influenced by trade liberalization (for the effects of CUSFTA see in particular Trefler, 2004, and Head and Ries, 1999). Since it is indeed through their influence on such variables that tariff cuts change incentives for M\&A, controlling for them would invalidly attribute less of the increase in takeover activity to freer trade. A similar criticism applies to a number of determinants that have been proposed in the Corporate Finance literature on M\&A activity, like capacity utilization, sales growth, free cash flow or relative price-earnings ratios (Mitchell and Mulherin, 1996; Mulherin and Boone, 2000; Andrade and Stafford, 2004; Gugler et al., 2004). In addition, some of these variables are of an inherently firm-level nature and thus unsuited for the present industry-level analysis. ${ }^{27}$

In the light of these difficulties, I choose to pursue a different route and try to control for time- and industry-varying factors other than tariff cuts by including the number of takeovers of firms in the same industry in the United Kingdom, France and (West) Germany. ${ }^{28}$ The idea behind this approach is that these countries were largely unaffected by CUSFTA and changes in takeover activity there should thus pick up any general industry-level trends in underlying M\&A determinants. Since many factors which might potentially influence takeover rates are highly correlated across developed countries, these trends are likely to be similar in Europe and in North America. Examples include oil price shocks, low sales growth and low capacity utilization combined with large amounts of free cash flow in declining industries, or strongly increasing price-earnings ratios in times of stock market bubbles. Indeed, the simple correlation between the number of European and U.S. or Canadian M\&A transactions per-period and industry is on average about $70 \%$. Note that I exclude any acquisitions of North American firms in Europe or vice versa from the EU numbers. This avoids endogeneity problems arising from the fact that M\&A transactions in North America could be a substitute for cross-Atlantic transactions in some cases. ${ }^{29}$

Lines 4-6 of table 3 show the results for all three tariff cut measures with the controls in place. I use domestic M\&A in the UK, France and Germany as the control for the

\footnotetext{
${ }^{27}$ Variables of this type analyzed in the literature are Tobin's q, free cash flow, and price-earnings ratios. As discussed for example by Andrade and Stafford (2004), there is no straightforward way to aggregate these determinants from the firm to the industry level since their impact is highly non-linear or depends on differences between targets and acquirers.

${ }^{28}$ These are the three developed countries besides Canada and the U.S. for which M\&A coverage in Thomson Financial is reasonably complete back to 1985 .

${ }^{29} \mathrm{~A}$ remaining issue might arise from the implementation of the European Common Market during the period 1986-1992. However, the impact on M\&A activity through changes in manufacturing trade is likely to have been small. This is since much more substantial measures like duty-free trade, common external tariffs and many common sectoral policies had already been in place for more than a decade by 1986. A more novel aspect of the common market was the liberalization of cross-border capital flows. This measure, however, showed little cross-sectoral variation and should as such be captured by my period fixed effects.
} 
two regressions on domestic M\&A activity and all cross-border M\&A with targets in one of these three countries as the control for the cross-border categories (excluding acquisitions by U.S. or Canadian firms). As seen, the coefficients estimates are very similar to the earlier results, consistent with the idea that industry and time fixed effects already captured most of the influence of non-tariff related determinants of M\&A activity.

Results for Different Subsamples I perform further robustness checks by looking at specific subsamples of M\&A transactions. I start by excluding the acquirer SIC-code 6799 ("Investors, n.e.c."). As discussed earlier, a large fraction of this category is made up by private equity and venture capital firms as well as private investors, groups which do not neatly fit into the earlier theoretical framework. However, results are basically unaffected by the exclusion of this group as is shown in the first three lines of table 4 .

Next, I drop acquisitions of minority interests from my sample, i.e. transactions at the end of which the acquirer holds less than $50 \%$ of control rights or held more than $50 \%$ to begin with. The corresponding coefficient estimates (lines 4-6) show a slightly stronger impact of tariff cuts on domestic Canadian M\&A activity while estimates for domestic U.S. transactions drop somewhat and are now mostly statistically insignificant (except for the binary tariff cut measure).

In lines 7-9, I look at M\&A transactions taking place within identical three-digit manufacturing industries. These specifications are thus closest to the theoretical model presented in section 2 which looked at within-sector acquisitions. From the regression results it appears that CUSFTA affected within-sector M\&A activity in broadly similar ways to overall M\&A activity. The one noticeable exception is a strong increase in the coefficient magnitude for U.S.-by-Canada-acquisitions when absolute tariff changes are used as a regressor (although this change is not repeated for the other functional forms).

Finally, I restrict my sample to include only transactions involving publicly traded firms. This is of interest since the following sections, which look at target and acquirer characteristics and the quantitative importance of $\mathrm{M} \& \mathrm{~A}$ as a form of reallocation, will almost exclusively rely on data for publicly traded firms. It is thus useful to check whether the qualitative results found so far also apply to this particular subsample of firms. In addition, publicly traded firms tend to be bigger and are more likely to be exporters which suggests that CUSFTA's impact may indeed have been different for this group. However, lines 10-12 of table 4 show that this is not the case for domestic M\&A activity. The cross-border M\&A regressions, in contrast, do show somewhat stronger results for this subsample. U.S. acquisitions by Canadian firms seem to be more affected by CUSFTA now, with coefficients mostly being significant and large in absolute magnitude. Also, U.S. acquisitions in Canada are positively related to tariff cuts in this subsample although none of the estimates are statistically significant. 
Changes in Competition Policy as an Alternative Explanation? As the above graphs and estimations make clear, the main reaction from CUSFTA seems to have come from domestic Canadian M\&A activity. This brings up an alternative explanation for the results found so far. Canadian competition authorities might have become more lenient vis-à-vis domestic M\&A activity given increased competition from U.S. firms. If this relaxation of supervision was correlated with the extent of Canadian tariff cuts (e.g. because the competition authorities took them into account in their definition of the relevant market), this could provide an alternative explanation for my results. Note, however, that such a policy change is not incompatible with M\&A as a means of resource transfer: the need for industrial restructuring after CUSFTA could have been the underlying cause for increased M\&A activity and a more lenient stance from the competition authorities may have merely facilitated the adjustment. One would thus need the additional argument that Canadian industries were already poised for consolidation before CUSFTA and that relaxation of merger guidelines then eliminated restraining regulatory barriers. While it is difficult to definitely exclude this possibility, documents and statements published by the Canadian Competition Bureau do not show any support for this hypothesis. ${ }^{30}$ Also, if a looser competition policy was responsible for the surge in M\&A activity one would expect to see a far stronger effect for within-industry transactions which is not the case. ${ }^{31}$

\section{Comparison of Acquirers and Targets}

The last sections have provided evidence that CUSFTA led to an increase in M\&A activity, in particular in Canada and both within and between industries. This section looks in more detail at the characteristics of acquirers and targets in order to determine whether the resulting inter-firm transfer of resources is similar in nature to the one involved in firm and establishment exit and contraction. The existing literature has shown that it is usually the less productive firms and plants that contract or exit. While it is typically not possible to track the employment of factors of production in these studies, the parallel expansion of high productivity establishments seems to indicate that they re-employ at least part of the freed-up resources. The question thus arises whether M\&A similarly leads to a channeling of resources towards more productive owners. This also has important implications for M\&A-induced changes in aggregate productivity since existing studies have demonstrated that post-takeover gains in the target's productivity depend crucially on a superior efficiency of the acquiring firm (e.g. Maksimovic and Phillips,

\footnotetext{
${ }^{30}$ See http://www.competitionbureau.gc.ca/ and in particular the revised "Merger Enforcement Guidelines" from 1991.

${ }^{31} \mathrm{~A}$ bigger increase would be expected for this category since horizontal M\&A is the main focus of the competition authorities. According to the Canadian Competition Bureau (1991) vertical and conglomerate M\&A transactions were rarely the object of regulatory restrictions.
} 
2001).

A simple way of comparing targets and acquirers is to regress proxies for firm performance on dummies for whether a company is a target or an acquirer in a transaction. For this, I use data from Compustat North America and Compustat Global as described in section 4. I start by looking at net sales and the number of employees to get an impression of the size differences between targets and acquirers. Next, I compare levels of profitability, using pretax income per employee and pretax income per net sales as proxies. Recall from the theoretical section of this paper that more productive firms were predicted to be both larger and more profitable than less productive firms. Thus the above comparisons might also be seen as a first check on underlying productivity differences. Since in practice, differences in size and profitability might also be due to other factors, I additionally use labor and total factor productivity as more direct proxies. ${ }^{32}$

The basic econometric specification I estimate is:

$$
y_{t j}=\alpha+d_{t}+\beta_{1} \times \text { target }_{t j}+\varepsilon_{t j}
$$

where $y_{t j}$ is the performance indicator of interest for company $j$ at time $t$ (where $t$ denotes the last completed fiscal year prior to the takeover announcement). The $d_{t}$ represent time fixed effects and target $_{t j}$ is a dummy that takes the value one if the company in question is a target. ${ }^{33}$ The coefficient of interest is thus $\beta_{1}$ which gives the difference between targets and acquirers (which are the omitted category). Block 1 of table 5 shows results for these baseline regressions. Acquirers are found to be significantly bigger in terms of net sales and the number of employees (columns 1 and 2). In addition, both pretax income measures indicate that acquirers are also substantially more profitable (columns 3 and 4). Interestingly, using estimates of $\alpha, d_{t}$ and $\beta_{1}$ for these specifications, one finds for most years of the sample that targets were on average making slight losses prior to takeover. Finally, the productivity differences between acquirers and targets are also significantly positive. For labor productivity, the acquirers' advantage is somewhat more pronounced than for total factor productivity ( $12 \%$ as opposed to $4 \%$ ) which seems to be

\footnotetext{
${ }^{32} \mathrm{My}$ TFP figures are calculated from a two-factor Cobb-Douglas production function under the assumption of constant returns to scale (the two factors are labor and capital and I assume an elasticity of value added with respect to labor of 0.66). Note that since Compustat does not provide information on intermediate inputs, I use output (net sales) as my proxy for value added and assume that variations in the intermediate share are not systematically related to target or acquirer status.

${ }^{33}$ Note that specification (7) pools all available data for targets and acquirers rather than calculating a target-acquirer difference for each merger and estimating the mean difference. This is necessary since for most mergers I do not have financial data on both parties. Note that for a given sample of mergers without missing data these two approaches are identical. Also, while pooling data increases the number of acquirers relative to targets (because data availability is generally better for larger firms and acquirers tend to be larger), the resulting bias is likely to work against and not in favor of finding significant differences. This is since it is the smaller targets that get excluded from the sample (and since - at least in my sample - smaller size in terms of either net sales or employment is associated with lower profitability and productivity).
} 
due to a higher capital intensity among acquirers.

My baseline estimate of $\beta_{1}$ is an average across all four M\&A categories, i.e. U.S. and Canadian domestic transactions and the two cross-border categories. Next, I allow for acquirer-target differences to vary across these groups by estimating separate intercepts and slopes for all four types of M\&A transactions:

$$
y_{t j}=\alpha_{C A T}+d_{t}+\beta_{1} \times \operatorname{tar} U U_{t j}+\beta_{2} \times \operatorname{tar} C C_{t j}+\beta_{3} \times \operatorname{tar} U C_{t j}+\beta_{4} \times \operatorname{tar} C U_{t j}+\varepsilon_{t j}
$$

where $\alpha_{C A T}$ are the category specific intercepts and $\operatorname{tar} U U_{t j}, \operatorname{tar} C C_{t j}, \operatorname{tar} U C_{t j}$, and $\operatorname{tar} C U_{t j}$ are binary variables indicating whether a company is a target in one of the four types of transactions (for example, $\operatorname{tar} U C_{t j}$ equals one if company $j$ is the U.S. target of a Canadian acquirer). Results on the four target dummy coefficients are shown in block 2 of table 5 . Target-acquirer differences for the non-productivity indicators (net sales, employees and the two pretax income measures) are qualitatively similar to the first specification. However, the productivity estimates reveal some interesting changes. First, differences in both labor and total factor productivity seem to be considerably more pronounced for domestic Canadian M\&A transactions (acquirers are about 17\% and $13 \%$ more productive, respectively). For domestic U.S. transactions, the productivity advantage of acquirers is somewhat lower $(12 \%$ for labor productivity and $3.7 \%$ for TFP) but still highly significant. Third, estimates for acquisitions made by U.S firms in Canada also show acquirers to be more productive than targets, in particular with respect to total factor productivity. In contrast, the productivity differences for Canadian-U.S. acquisitions are both insignificant and the TFP estimate is actually positive. One potential explanation might be that there are gains for Canadian firms that go beyond a pure reallocation story where acquirers improve the target firm's productivity (e.g. access to superior technology in the U.S. market). For all other categories, however, it seems that resources are transferred from less to more profitable and productive firms.

In a last step, I augment specification (8) with industry fixed effects to control for possible variation in company characteristics across sectors. Block 3 of table 5 contains estimates for this final specification which are very similar to the results from (8). Since $\beta_{1}$ to $\beta_{4}$ are now identified from within-industry variation, this also indicates that acquirertarget differences are similar irrespective of whether transactions are of cross- or withinindustry nature. 


\section{The Quantitative Importance of the M\&A Chan- nel}

The findings so far are supportive of the view that CUSFTA triggered an increase in resource transfers via M\&A, especially in the smaller Canadian market. It also seems that these transfers were in most cases from less to more profitable and productive firms, similar to the channels analyzed in the previous literature (i.e. contraction and closure). A question that naturally arises from these observations is how important inter-firm resource transfers via $\mathrm{M} \& \mathrm{~A}$ are quantitatively, both in absolute terms and relative to the two other forms of adjustment to freer trade.

While the absence of a control group of firms not engaging in M\&A in the Thomson Financial dataset prevents me from giving a definitive answer to this question, some progress can be made in a more indirect way. In particular, the available data allow an analysis of how important resource transfers via M\&A are in general, i.e. not necessarily linked to trade liberalization. Against this baseline, the earlier estimates of CUSFTA's impact on M\&A activity can be judged on their quantitative importance.

To evaluate the general quantitative importance of M\&A, I rely again on information for publicly traded firms from Compustat North America and Compustat Global as described in section 4. Of the 331 Canadian and 5816 U.S. firms contained in the Compustat sample, about a quarter exits during the sample period due to M\&A or bankruptcy related reasons with $\mathrm{M} \& \mathrm{~A}$ accounting for $82 \%$ of all exits (see table 6 ). That is, M\&A seems to be by far the most important exit form for publicly traded firms in North America. $^{34}$

Table 7 delves deeper by quantifying the average annual amount of jobs and production (net sales) transferred through the two exit forms. In addition, I also look at the third form of moving resources away from contracting firms, i.e. decreases in employment and sales at continuing companies. The resulting figures show that while reductions at existing firms are the most important channel, M\&A is responsible for about $25 \%$ of joband $30 \%$ of sales volume redeployment. These figures are very similar for both the U.S. and Canada and demonstrate that M\&A is indeed a quantitatively important way of transferring resources between firms. For the publicly traded companies analyzed here, it

\footnotetext{
${ }^{34}$ Note that one alternative to the approach taken here would be to use the Compustat sample to estimate the impact of trade on the three adjustment channels, e.g. using a multinomial probit model. However, this would only give an estimate of the impact of trade liberalization on the relative incidence of the channels rather than the magnitude of the resource transfer involved. More importantly, there are some important limitations of the Compustat sample which prevent such a more detailed analysis. Most importantly, the focus on publicly traded firms means the number of Canadian firms is too small for the level of disaggregation used here (I have 140 sectors but only have exit information on 331 firms in Canada). In addition, I have no information on acquirers so that I cannot perform splits into the impact of CUSFTA on cross-border and domestic activity which was found to be very different. Finally, there are some issues related to the timing of exit and M\&A since the date of deletion from Compustat need not correspond exactly to the actual transaction date.
} 
also far outweighs exit via bankruptcy as the third adjustment channel. ${ }^{35}$ It is likely that exit by bankruptcy will be more important among smaller, non-publicly traded companies and that turnover at continuing firms will also be higher for this group (see Davis et al., 1996). On the other hand, it has already been pointed out that publicly traded firms account for over $80 \%$ of manufacturing output and employment in North America. Thus, the overall quantitative importance of $\mathrm{M} \& \mathrm{~A}$ is unlikely to decrease by much in a more comprehensive sample. Combined with the earlier findings that CUSFTA led to large increases in domestic M\&A activity in Canada (over $60 \%$ according to my estimates), these results suggest that the amount of resource transfer involved was indeed substantial.

\section{Conclusions}

This paper examined the empirical relevance of mergers and acquisitions (M\&A) as a channel of firm-level adjustment to trade liberalization. Guided by the insights from a simple theoretical model, I used the Canada-U.S. Free Trade Agreement (CUSFTA) of 1989 to estimate the impact of freer trade on M\&A activity. I argued that CUSFTA provided an ideal setting for this purpose in many ways. It was a liberalization agreement between industrialized countries with comparatively few restrictions on takeovers; it represented a source of unanticipated and largely exogenous variation in trade barriers; and its main instrument - tariff cuts - was a direct and easily quantifiable trade policy measure with substantial sectoral variation. Implementing a difference-in-differences identification strategy, I found a rich set of results. While there does not seem to be a robust link between cross-border M\&A and trade liberalization, resource transfer via M\&A between domestic firms is an empirically relevant phenomenon. This is particularly true for Canada, where I estimated a tariff cut-related increase in domestic M\&A activity of over $60 \%$. There also seems to have been an effect on domestic U.S. transactions, albeit a substantially smaller one which is consistent with the idea that CUSFTA presented a much less important trade shock for the large American market.

In order to compare resource transfers via M\&A to adjustment via firm- and establishment contraction and exit, I further presented evidence on the nature and quantitative importance of the M\&A channel. Using a large sample of publicly traded firms, I found that $\mathrm{M} \& \mathrm{~A}$ involved a rechannelling of resources from low to high productivity firms (in particular for the domestic transactions) and that its magnitude is likely to have been quantitatively important. Taken together, these results suggest that for firms adapting to freer trade, $\mathrm{M} \& \mathrm{~A}$ represents an important alternative to adjustment via closure,

\footnotetext{
${ }^{35}$ Note that sell-offs or closures of individual divisions or plants will show up under the "reduction at continuing firms" category (exit by M\&A or bankruptcy in Compustat only occurs if the entire firm is acquired or goes bankrupt). Insofar, the results for the two exit categories can be seen as the lower bound to what would be obtained from a plant-level analysis.
} 
contraction, or internal expansion.

There are a number of interesting implications arising from these findings. In particular, they highlight the fact that adjustment to freer trade can take less drastic forms than firm- and plant closure and the associated mass layoffs of workers and liquidation of capital. Indeed, if M\&A does represent a swifter and more efficient way of transferring resources between firms, this would have important implications for competition policy. In particular, one would like antitrust authorities to facilitate the necessary transfer of resources by reducing restrictions on acquisitions in the wake of trade liberalizations. Given the generally higher level of restrictions imposed on M\&A activity in developing countries, this proposition could be of particular relevance there. This line of thought is reminiscent of certain strands in the Corporate Finance literature (in particular Jensen, 1993) which argue that takeovers represent a far superior way of restructuring industries than internal adjustments or bankruptcy and as such should not face unnecessary legal restrictions. ${ }^{36}$

This paper has provided evidence that M\&A is an important element of firm-level reactions to trade liberalization. The findings presented here suggest a number of important areas for further research. For example, it would be of interest to replicate my results for trade liberalization episodes in developing countries where different regulatory environments, lower stock market capitalization and more restricted availability of credit might imply a different and possibly more restricted role for M\&A. Another promising extension would be to investigate in more detail how M\&A compares to the alternative adjustment channels of exit and internal expansion or contraction. Besides looking at how firm- and industry-characteristics influence the choice of adjustment strategy, I am particularly interested in providing evidence on the relative efficiency of the different channels. Using certain exogenous restrictions on M\&A (ownership structure, legal barriers to acquisitions etc.), it should in principle be possible to compare the performance of firms and industries that were able to use M\&A as an adjustment mechanism with other firms and industries that had to rely on other forms of adjustment.

\footnotetext{
${ }^{36}$ Some tentative evidence supporting the efficiency of the M\&A channel comes from the observation that M\&A seems to lead to overall efficiency gains in most periods and settings (see Andrade et al., 2001, for a detailed survey). In contrast, liquidation costs are usually found to be substantial, with asset values decreasing by over $50 \%$ (see Jovanovic and Rousseau, 2004).
} 


\section{Figures and Tables}

\section{Table 1: Descriptive Statistics on Target Industries}

\begin{tabular}{|c|c|c|c|c|c|c|c|c|c|}
\hline \multirow[b]{2}{*}{$\begin{array}{l}\text { U.S.- } \\
\text { SIC87 } \\
\text { (2-digit) }\end{array}$} & \multirow[b]{2}{*}{ Industry Name } & \multicolumn{4}{|c|}{ Total No. of Acquisitions 1985-1997 } & \multirow[b]{2}{*}{$\begin{array}{c}(5) \\
\text { \#Establishments } \\
\text { (U.S.) }\end{array}$} & \multirow[b]{2}{*}{$\begin{array}{c}(6) \\
\text { \#Establishments } \\
\text { (Canada) }\end{array}$} & \multirow[b]{2}{*}{$\begin{array}{c}\text { (7) Avg. U.S. } \\
\text { import tariff in } \\
1988\end{array}$} & \multirow[b]{2}{*}{$\begin{array}{c}\text { (8) Avg. Can. } \\
\text { import tariff in } \\
1988\end{array}$} \\
\hline & & $\begin{array}{c}\text { (1) U.S. by } \\
\text { U.S. }\end{array}$ & $\begin{array}{l}\text { (2) U.S. by } \\
\text { CAN }\end{array}$ & $\begin{array}{l}\text { (3) CAN by } \\
\text { U.S. }\end{array}$ & $\begin{array}{l}\text { (4) CAN by } \\
\text { CAN }\end{array}$ & & & & \\
\hline 20 & Food and kindred products & 1497 & 46 & 52 & 219 & 20,749 & 3,440 & $3.9 \%$ & $5.9 \%$ \\
\hline 21 & Tobacco manufactures & 40 & 0 & 0 & 2 & 119 & 20 & $20.7 \%$ & $14.4 \%$ \\
\hline 22 & Textile mill products & 385 & 11 & 16 & 37 & 6,035 & 757 & $8.7 \%$ & $13.5 \%$ \\
\hline 23 & Apparel and other textile products & 478 & 8 & 11 & 16 & 23,224 & 2,604 & $9.4 \%$ & $15.8 \%$ \\
\hline 24 & Lumber and wood products & 257 & 15 & 14 & 90 & 22,665 & 3,110 & $2.2 \%$ & $4.5 \%$ \\
\hline 25 & Furniture and fixtures & 314 & 3 & 2 & 32 & 11,796 & 1,927 & $2.2 \%$ & $10.7 \%$ \\
\hline 26 & Paper and allied products & 531 & 30 & 19 & 125 & 6,401 & 818 & $3.4 \%$ & $8.8 \%$ \\
\hline 27 & Printing and publishing & 1873 & 69 & 30 & 209 & 63,179 & 5,425 & $0.5 \%$ & $2.0 \%$ \\
\hline 28 & Chemicals and allied products & 2550 & 70 & 65 & 135 & 12,138 & 1,204 & $3.8 \%$ & $6.2 \%$ \\
\hline 29 & Petroleum and coal products & 216 & 9 & 8 & 21 & 2,168 & 140 & $0.7 \%$ & $0.8 \%$ \\
\hline 30 & Rubber and misc. plastics products & 819 & 27 & 31 & 64 & 15,774 & 1,607 & $4.5 \%$ & $8.8 \%$ \\
\hline 31 & Leather and leather products & 121 & 0 & 3 & 4 & 2,026 & 320 & $7.5 \%$ & $12.6 \%$ \\
\hline 32 & Stone, clay, glass, and concrete products & 389 & 15 & 20 & 42 & 16,279 & 1,612 & $1.8 \%$ & $3.9 \%$ \\
\hline 33 & Primary metal industries & 749 & 21 & 38 & 73 & 6,479 & 515 & $3.4 \%$ & $4.5 \%$ \\
\hline 34 & Fabricated metal products & 1076 & 38 & 38 & 82 & 36,835 & 3,236 & $2.2 \%$ & $7.0 \%$ \\
\hline 35 & Industrial machinery and equipment & 2843 & 72 & 98 & 189 & 54,143 & 4,635 & $2.6 \%$ & $5.2 \%$ \\
\hline 36 & Electrical and electronic equipment & 2657 & 71 & 87 & 162 & 16,649 & 988 & $3.5 \%$ & $6.3 \%$ \\
\hline 37 & Transportation equipment & 999 & 24 & 36 & 87 & 11,393 & 1,256 & $0.9 \%$ & $5.5 \%$ \\
\hline 38 & Instruments and related products & 2254 & 30 & 39 & 53 & 11,091 & 987 & $4.2 \%$ & $7.0 \%$ \\
\hline 39 & Miscellaneous manufacturing industries & 612 & 17 & 15 & 21 & 17,217 & 1,720 & $3.8 \%$ & $6.2 \%$ \\
\hline
\end{tabular}

Notes: Columns 1-4 show the total number of takeovers of firms with primary activity in manufacturing (SIC 20-39) during 1985-1997. The columns give figures by two-digit industry for four different M\&A

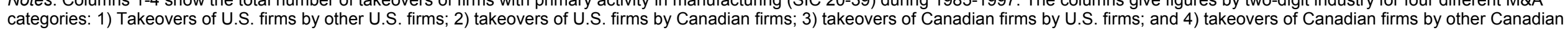

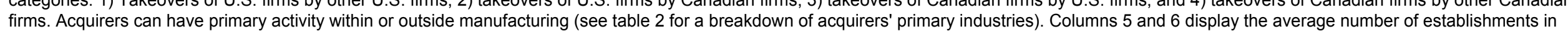
1985-1997 for the U.S. and Canada. Columns 7 and 8 show two-digit average import tariffs levied by the U.S. and Canada on each other's manufacturing products in 1988 . 


\section{Table 2: Descriptive Statistics on Acquirer Industries}

United States

\begin{tabular}{|c|c|c|c|c|c|c|c|c|}
\hline Sector & (1) Number & $\begin{array}{c}\text { (2) \% of total } \\
\text { manufacturing } \\
\text { M\&A }\end{array}$ & $\begin{array}{l}\text { (3) secondary SIC } \\
\text { in manuf. }(\%)\end{array}$ & $\begin{array}{l}\text { (4) at least one 3- } \\
\text { digit SIC-code in } \\
\text { common with } \\
\text { target }(\%)\end{array}$ & (5) Number & $\begin{array}{c}(6) \% \text { of total } \\
\text { manufacturing } \\
\text { M\&A }\end{array}$ & $\begin{array}{c}\text { (7) secondary } \\
\text { SIC in manuf. } \\
(\%)\end{array}$ & $\begin{array}{l}\text { (8) at least one 3- } \\
\text { digit SIC-code in } \\
\text { common with } \\
\text { target }(\%)\end{array}$ \\
\hline Manufacturing firms (SIC 2-3) & 14878 & $70.1 \%$ & $100.0 \%$ & $55.0 \%$ & 1583 & $69.3 \%$ & $100.0 \%$ & $58.5 \%$ \\
\hline - Same 3-digit industry & 7168 & $33.8 \%$ & $100.0 \%$ & $100.0 \%$ & 831 & $36.4 \%$ & $100.0 \%$ & $100.0 \%$ \\
\hline - Same 2-digit industry but not same 3-digit industry & 2808 & $13.2 \%$ & $100.0 \%$ & $13.0 \%$ & 303 & $13.3 \%$ & $100.0 \%$ & $15.9 \%$ \\
\hline - Different 2-digit industries & 4902 & $23.1 \%$ & $100.0 \%$ & $8.5 \%$ & 449 & $19.6 \%$ & $100.0 \%$ & $4.7 \%$ \\
\hline Non-manufacturing firms & 3555 & $16.7 \%$ & $26.1 \%$ & $3.0 \%$ & 472 & $20.7 \%$ & $22.6 \%$ & $2.7 \%$ \\
\hline - Agriculture, Fishing \& Hunting (sic 1) & 69 & $0.3 \%$ & $50.7 \%$ & $5.8 \%$ & 10 & $0.4 \%$ & $50.0 \%$ & $10.0 \%$ \\
\hline - Mining (sic 10-14) & 260 & $1.2 \%$ & $29.7 \%$ & $1.1 \%$ & 65 & $2.8 \%$ & $10.6 \%$ & $0.0 \%$ \\
\hline - Construction (sic 15-17) & 96 & $0.5 \%$ & $32.3 \%$ & $2.1 \%$ & 8 & $0.4 \%$ & $50.0 \%$ & $0.0 \%$ \\
\hline - Transportation, communications, and utilities (sic 4) & 417 & $2.0 \%$ & $28.1 \%$ & $2.4 \%$ & 62 & $2.7 \%$ & $45.2 \%$ & $0.0 \%$ \\
\hline - Wholesale trade (sic 50-51) & 713 & $3.4 \%$ & $36.7 \%$ & $6.2 \%$ & 77 & $3.4 \%$ & $24.7 \%$ & $5.2 \%$ \\
\hline - Retail Trade (sic 52-59) & 206 & $1.0 \%$ & $17.5 \%$ & $3.9 \%$ & 24 & $1.1 \%$ & $20.8 \%$ & $4.2 \%$ \\
\hline - Finance, insurance, and real estate (sic 60-67) & 693 & $3.3 \%$ & $10.1 \%$ & $0.1 \%$ & 140 & $6.1 \%$ & $1.4 \%$ & $0.0 \%$ \\
\hline - Services industry (sic 7/8) & 1078 & $5.1 \%$ & $27.6 \%$ & $3.1 \%$ & 86 & $3.8 \%$ & $43.0 \%$ & $8.1 \%$ \\
\hline - Government (sic 9) & 23 & $0.1 \%$ & $0.0 \%$ & $0.0 \%$ & 14 & $0.6 \%$ & $0.0 \%$ & $0.0 \%$ \\
\hline Investors, n.e.c (sic 6799) & 2803 & $13.2 \%$ & $0.0 \%$ & $0.0 \%$ & 216 & $9.5 \%$ & $0.0 \%$ & $0.0 \%$ \\
\hline Total number of manufacturing $M \& A$ & 21236 & $100.0 \%$ & & & 2285 & $100.0 \%$ & & \\
\hline
\end{tabular}

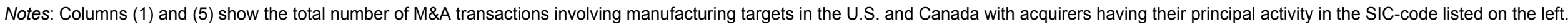
Columns (2) and (6) express these numbers as \% of the total number of manufacturing M\&A transaction in the respective country. Columns (3) and (7) list the fraction of acquirers from a given SIC-code that have a primary OR secondary three-digit SIC-code in manufacturing. Columns (4) and (8) similarly list the fraction of acquirers that have at least one three-digit manufacturing SIC-code (primary or secondary) in common with the target. 


\section{Table 3: Impact of tariff reductions on number of M\&A transactions - Full Sample}

Dependent Variable: Number of Takeovers

\begin{tabular}{|c|c|c|c|c|c|c|c|c|c|c|c|c|c|c|}
\hline \multirow{2}{*}{\multicolumn{2}{|c|}{ Measure of tariff cuts $(\Delta)$}} & \multicolumn{3}{|c|}{ 1) Canada by Canada } & \multicolumn{3}{|c|}{ 2) U.S. by Canada } & \multicolumn{3}{|c|}{ 3) U.S. by U.S. } & \multicolumn{3}{|c|}{ 4) Canada by U.S. } & \multirow[t]{2}{*}{ Controls } \\
\hline & & $\beta_{\text {cbyc }}$ & $d_{\text {post }}$ & Obs. & $\beta_{u b y c}$ & $d_{\text {post }}$ & Obs. & $\beta_{\text {ubyu }}$ & $d_{\text {post }}$ & Obs. & $\beta_{\text {cbyu }}$ & $d_{\text {post }}$ & Obs. & \\
\hline \multirow[t]{2}{*}{ (1) } & $\Delta=\log \left(t_{1988} t^{-t_{1997}}\right)$ & 0.365 & 2.887 & 280 & 0.103 & 1.121 & 280 & 0.068 & 0.752 & 280 & 0.076 & 1.755 & 280 & No \\
\hline & & $(4.18)^{\star \star}$ & $(10.14)^{\star \star}$ & & $(0.97)$ & $(2.81)^{* *}$ & & $(3.68)^{\star \star}$ & $(11.17)^{\star \star}$ & & $(0.45)$ & $(3.41)^{\star \star}$ & & \\
\hline \multirow[t]{2}{*}{ (2) } & $\Delta=\mathrm{t}_{1988}-\mathrm{t}_{1997}$ & 8.310 & 1.295 & 280 & 6.940 & 0.448 & 280 & 0.979 & 0.471 & 280 & -6.561 & 1.941 & 280 & No \\
\hline & & $(3.58)^{* *}$ & $(10.04)^{\star *}$ & & $(1.52)$ & $(2.98)^{\star \star}$ & & $(1.89)^{+}$ & $(19.45)^{\star *}$ & & $(1.80)+$ & $(7.89)^{\star \star}$ & & \\
\hline \multirow[t]{2}{*}{ (3) } & $\Delta=1\left(\mathrm{dt}>\mathrm{dt}_{, 50 \%}\right)$ & 0.370 & 1.554 & 280 & 0.479 & 0.417 & 280 & 0.224 & 0.380 & 280 & -0.250 & 1.681 & 280 & No \\
\hline & & $(2.77)^{\star \star}$ & $(18.52)^{\star \star}$ & & $(3.01)^{\star *}$ & $(3.87)^{\star \star}$ & & $(8.74)^{\star *}$ & $(20.16)^{\star \star}$ & & $(1.23)$ & $(11.02)^{\star \star}$ & & \\
\hline \multirow[t]{2}{*}{ (4) } & $\Delta=\log \left(\mathrm{t}_{1988}-\mathrm{t}_{1997}\right)$ & 0.364 & 2.871 & 280 & 0.090 & 0.787 & 280 & 0.069 & 0.708 & 280 & 0.119 & 1.698 & 280 & Yes \\
\hline & & $(4.12)^{\star \star}$ & $(9.15)^{\star \star}$ & & $(0.85)$ & $(1.85)+$ & & $(3.71)^{\star *}$ & $(10.07)^{\star \star}$ & & $(0.67)$ & $(2.93)^{\star \star}$ & & \\
\hline \multirow[t]{2}{*}{ (5) } & $\Delta=\mathrm{t}_{1988}-\mathrm{t}_{1997}$ & 8.419 & 1.265 & 280 & 6.885 & 0.137 & 280 & 1.224 & 0.434 & 280 & -6.598 & 1.811 & 280 & Yes \\
\hline & & $(3.57)^{\star *}$ & $(7.47)^{\star \star}$ & & $(1.53)$ & $(0.70)$ & & $(1.84)^{+}$ & $(11.98)^{\star *}$ & & $(1.78)^{+}$ & $(7.04)^{\star \star}$ & & \\
\hline \multirow[t]{2}{*}{ (6) } & $\Delta=1\left(\mathrm{dt}>\mathrm{dt}_{, 50 \%}\right)$ & 0.380 & 1.512 & 280 & 0.452 & 0.149 & 280 & 0.224 & 0.368 & 280 & -0.232 & 1.530 & 280 & Yes \\
\hline & & $(2.83)^{\star *}$ & $(13.56)^{\star \star}$ & & $(2.82)^{\star \star}$ & $(0.92)$ & & $(8.72)^{\star \star}$ & $(13.43)^{\star \star}$ & & (1.14) & $(8.43)^{\star \star}$ & & \\
\hline
\end{tabular}

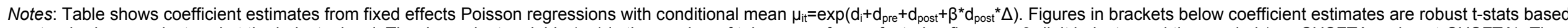

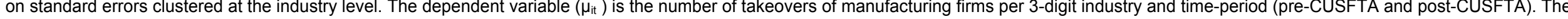
regressors are transformations of the absolute change in industry tariffs 1988-1997, interacted with a post-CUSFTA period-dummy (d $\mathrm{d}_{\text {post }}{ }^{*} \Delta$ ): lines 1 and 4 use logs of absolute changes, lines 2 and 5 use

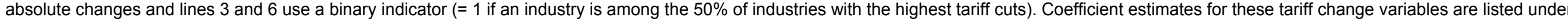
the first column of each M\&A category (columns containing $\beta$ s). The four categories included are: 1 ) takeovers of Canadian firms by other Canadian firms; 2 ) takeovers of U.S. firms by Canadian firms; 3 ) takeovers of U.S. firms by other U.S. firms; and 4) takeovers of Canadian firms by U.S. firms. All regressions also include industry fixed effects (d) and a period-dummy for the post-FTA period (estimates shown under the columns with the heading " $d_{\text {post }}$ "). The excluded category is the pre-CUSFTA period dummy $d_{\text {pre. }}$ Regressions $4-6$ additionally contain the number of takeovers in the EU in the same industry and time-period (see text for details).,$+{ }^{*}$ and ** indicate statistical significance at the $10 \%$, the $5 \%$ and the $1 \%$-level, respectively. 


\section{Table 4: Impact of tariff reductions on number of M\&A transactions - Subsamples}

\begin{tabular}{|c|c|c|c|c|c|c|c|c|c|c|c|c|c|c|c|}
\hline & \multicolumn{15}{|c|}{ Dependent Variable: Number of Takeovers } \\
\hline & \multirow{2}{*}{\multicolumn{2}{|c|}{$\begin{array}{l}\text { Measure of tariff cuts } \\
(\Delta)\end{array}$}} & \multicolumn{3}{|c|}{ 1) Canada by Canada } & \multicolumn{3}{|c|}{ 2) U.S. by Canada } & \multicolumn{3}{|c|}{ 3) U.S. by U.S. } & \multicolumn{3}{|c|}{ 4) Canada by U.S. } & \multirow[t]{2}{*}{ Controls } \\
\hline & & & $\beta_{\text {cbyc }}$ & $d_{\text {post }}$ & Obs. & $\beta_{\text {ubyc }}$ & $d_{\text {post }}$ & Obs. & $\beta_{\text {Ubyu }}$ & $d_{\text {post }}$ & Obs. & $\beta_{\text {Cbyu }}$ & $d_{\text {post }}$ & Obs. & \\
\hline \multirow{5}{*}{ 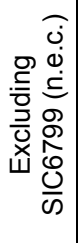 } & & $\Delta=\log \left(t_{1988}-t_{1997}\right)$ & 0.311 & $\begin{array}{r}2.613 \\
\end{array}$ & 280 & 0.152 & 1.093 & 280 & 0.045 & 0.693 & 280 & & 2.706 & 280 & Yes \\
\hline & (2) & $\Delta=\mathrm{t}_{1988}-\mathrm{t}_{1997}$ & 8.194 & 1.220 & 280 & 12.156 & 0.031 & 280 & 0.772 & 0.556 & 280 & -3.294 & 1.907 & 280 & Yes \\
\hline & & & $(3.20)^{\star \star}$ & $(6.72)^{\star \star}$ & & $(2.46)^{*}$ & $(0.15)$ & & $(0.99)$ & $(13.14)^{\star \star}$ & & $(0.82)$ & $(6.05)^{\star *}$ & & \\
\hline & (3) & $\Delta=1\left(\mathrm{dt}>\mathrm{dt}_{, 50 \%}\right)$ & 0.411 & 1.537 & 280 & 0.486 & 0.179 & 280 & 0.176 & 0.494 & 280 & -0.144 & 1.781 & 280 & Yes \\
\hline & & & $(2.79)^{\star \star}$ & $(12.04)^{\star \star}$ & & $(2.81)^{\star \star}$ & $(1.04)$ & & $(5.97)^{\star \star}$ & $(15.54)^{\star \star}$ & & $(0.67)$ & $(7.83)^{\star \star}$ & & \\
\hline \multirow{6}{*}{ 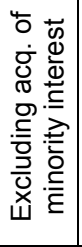 } & (4) & $\Delta=\log \left(t_{1988}-t_{1997}\right)$ & 0.422 & 2.878 & 280 & 0.045 & 0.741 & 280 & 0.023 & 0.506 & 280 & 0.246 & 2.365 & 280 & Yes \\
\hline & & & $(4.50)^{* *}$ & $(8.54)^{\star *}$ & & $(0.39)$ & $(1.60)$ & & $(1.18)$ & $(6.72)^{\star \star}$ & & $(1.30)$ & $(3.78)^{\star *}$ & & \\
\hline & (5) & $\Delta=\mathrm{t}_{1988} \mathrm{t}_{1997}$ & 9.135 & 1.021 & 280 & 5.421 & 0.262 & 280 & -0.256 & 0.442 & 280 & -4.733 & 1.919 & 280 & Yes \\
\hline & & & $(3.48)^{* *}$ & $(5.47)^{\star \star}$ & & $(1.11)$ & $(1.22)$ & & $(0.36)$ & $(11.40)^{\star \star}$ & & $(1.19)$ & $(5.94)^{\star \star}$ & & \\
\hline & (6) & $\Delta=1\left(\mathrm{dt}>\mathrm{dt}_{50 \%}\right)$ & 0.461 & 1.384 & 280 & 0.329 & 0.279 & 280 & 0.170 & 0.343 & 280 & -0.175 & 1.712 & 280 & Yes \\
\hline & & & $(3.05)^{\star \star}$ & $(10.61)^{\star *}$ & & $(1.87)^{+}$ & $(1.55)$ & & $(6.14)^{\star \star}$ & $(11.66)^{\star *}$ & & $(0.81)$ & $(7.45)^{\star \star}$ & & \\
\hline \multirow{6}{*}{ 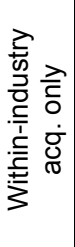 } & $(7)$ & $\Delta=\log \left(t_{1988}-t_{1997}\right)$ & 0.362 & 2.787 & 280 & -0.573 & -2.300 & 280 & 0.032 & 0.812 & 280 & 0.592 & 3.462 & 280 & Yes \\
\hline & & & $(2.30)^{*}$ & $(5.05)^{\star \star}$ & & $(1.48)$ & $(1.56)$ & & $(0.94)$ & $(6.19)^{\star \star}$ & & $(1.74)+$ & $(3.05)^{\star *}$ & & \\
\hline & (8) & $\Delta=\mathrm{t}_{1988} \mathrm{t}_{1997}$ & 7.385 & 1.223 & 280 & 24.876 & -1.162 & 280 & 1.645 & 0.660 & 280 & -1.135 & 1.706 & 280 & Yes \\
\hline & & & $(1.78)+$ & $(4.07)^{\star \star}$ & & $(2.50)^{*}$ & $(2.72)^{\star *}$ & & $(1.79)+$ & $(9.39)^{\star \star}$ & & $(0.14)$ & $(2.82)^{\star \star}$ & & \\
\hline & (9) & $\Delta=1\left(\mathrm{dt}>\mathrm{dt}_{, 50 \%}\right)$ & 0.384 & 1.521 & 280 & 0.365 & -0.653 & 280 & 0.294 & 0.561 & 280 & -0.602 & 1.950 & 280 & Yes \\
\hline & & & $(1.66)^{+}$ & $(7.40)^{\star *}$ & & $(1.04)$ & $(1.80)+$ & & $(6.20)^{\star \star}$ & $(10.48)^{\star *}$ & & $(1.61)$ & $(4.76)^{\star \star}$ & & \\
\hline \multirow{6}{*}{ 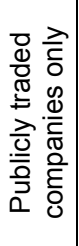 } & $(10)$ & $\Delta=\log \left(t_{1988}-t_{1997}\right)$ & 0.348 & 2.903 & 280 & 0.167 & 1.232 & 280 & 0.140 & 1.310 & 280 & 0.408 & 3.553 & 280 & Yes \\
\hline & & & $(2.99)^{* *}$ & $(5.80)^{\star \star}$ & & $(1.29)$ & $(2.37)^{*}$ & & $(5.28)^{\star \star}$ & $(12.91)^{\star \star}$ & & $(1.54)$ & $(3.87)^{\star \star}$ & & \\
\hline & (11) & $\Delta=\mathrm{t}_{1988} \mathrm{t}_{1997}$ & 8.715 & 1.934 & 280 & 19.963 & -0.097 & 280 & 2.518 & 0.731 & 280 & 3.117 & 2.102 & 280 & Yes \\
\hline & & & $(2.52)^{*}$ & $(7.70)^{* *}$ & & $(3.42)^{* *}$ & $(0.43)$ & & $(2.47)^{*}$ & $(13.69)^{\star *}$ & & $(0.47)$ & $(4.64)^{\star *}$ & & \\
\hline & $(12)$ & $\Delta=1\left(\mathrm{dt}>\mathrm{dt}_{50 \%}\right)$ & 0.368 & 2.298 & 280 & 0.766 & 0.156 & 280 & 0.254 & 0.705 & 280 & 0.219 & 2.175 & 280 & Yes \\
\hline & & & $(1.91)^{+}$ & $(12.79)^{\star *}$ & & $(4.04)^{* *}$ & $(0.86)$ & & $(6.93)^{* \star}$ & $(17.75)^{\star \star}$ & & $(0.77)$ & $(7.08)^{\star \star}$ & & \\
\hline
\end{tabular}

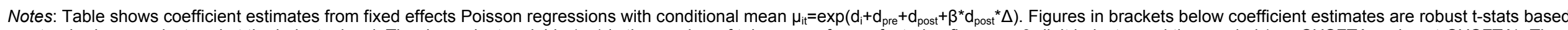

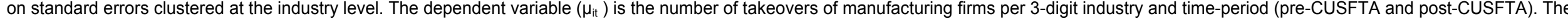
table displays results for four different subsamples of manufacturing targets (see first table column and text for details). The regressors are transformations of the absolute change in industry tariffs 1988-

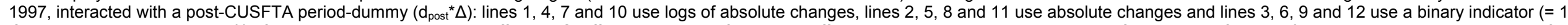

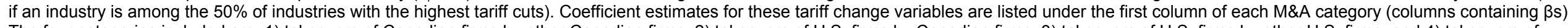

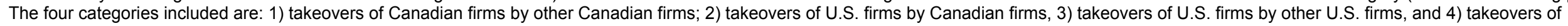

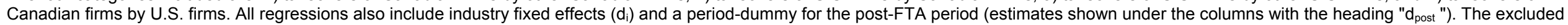
category is the pre-CUSFTA period $\left(\mathrm{d}_{\mathrm{pre}}\right)$. All regressions additionally contain the number of takeovers in the EU in the same industry and time-period (see text for details).,$+{ }^{*}$ and ${ }^{* *}$ indicate statistical significance at the $10 \%$, the $5 \%$ and the $1 \%$-level, respectively. 


\section{Table 5: Comparison Acquirers - Targets}

\begin{tabular}{|c|c|c|c|c|c|c|c|c|c|}
\hline $\begin{array}{l}\text { Specifi- } \\
\text { cation }\end{array}$ & Regressors & $\begin{array}{c}\text { (1) Net Sales (Mio } \\
1995 \text { USD) }\end{array}$ & $\begin{array}{l}\text { (2) Employees } \\
\text { ('000s) }\end{array}$ & $\begin{array}{l}\text { (3) Pretax income per } \\
\text { employee ('000 USD) }\end{array}$ & $\begin{array}{l}\text { (4) Pretax income } \\
\text { per net sales (USD) }\end{array}$ & $\begin{array}{l}\text { (5) Labor product. } \\
\text { (logs) }\end{array}$ & (6) TFP (logs) & $\begin{array}{c}\text { Year } \\
\text { dummies? }\end{array}$ & $\begin{array}{c}\text { Three-digit } \\
\text { industry } \\
\text { dummies? }\end{array}$ \\
\hline \multirow{3}{*}{ (1) } & Constant & $\begin{array}{l}970.057 \\
(12.24)^{\star *}\end{array}$ & $\begin{array}{c}11.112 \\
(11.36)^{\star *}\end{array}$ & $\begin{array}{l}9.168 \\
(6.24)^{\star *}\end{array}$ & $\begin{array}{l}0.052 \\
(6.62)^{\star *}\end{array}$ & $\begin{array}{c}4.899 \\
(130.61)^{* *}\end{array}$ & $\begin{array}{c}3.761 \\
(123.13)^{\star *}\end{array}$ & \multirow{3}{*}{ Yes } & \multirow{3}{*}{ No } \\
\hline & Target dummy & $\begin{array}{l}-882.693 \\
(11.91)^{\star *}\end{array}$ & $\begin{array}{l}-8.508 \\
(9.94)^{* *}\end{array}$ & $\begin{array}{l}-14.657 \\
(5.58)^{\star *}\end{array}$ & $\begin{array}{l}-0.096 \\
(7.92)^{* *}\end{array}$ & $\begin{array}{l}-0.120 \\
(5.08)^{* *}\end{array}$ & $\begin{array}{l}-0.040 \\
(2.45)^{\star}\end{array}$ & & \\
\hline & R-squared & 0.14 & 0.09 & 0.14 & 0.12 & 0.06 & 0.04 & & \\
\hline \multirow{5}{*}{ (2) } & Target CAN by CAN & $\begin{array}{l}-656.089 \\
(4.51)^{* *}\end{array}$ & $\begin{array}{l}-5.506 \\
(2.41)^{*}\end{array}$ & $\begin{array}{l}-8.483 \\
(2.51)^{*}\end{array}$ & $\begin{array}{l}-0.074 \\
(5.27)^{\star *}\end{array}$ & $\begin{array}{l}-0.169 \\
(2.90)^{* *}\end{array}$ & $\begin{array}{l}-0.129 \\
(3.09)^{\star *}\end{array}$ & \multirow{5}{*}{ Yes } & \multirow{5}{*}{ No } \\
\hline & Target U.S. by U.S. & $\begin{array}{l}-890.943 \\
(11.38)^{* *}\end{array}$ & $\begin{array}{l}-8.589 \\
(9.50)^{\star *}\end{array}$ & $\begin{array}{l}-14.666 \\
(5.57)^{\star *}\end{array}$ & $\begin{array}{l}-0.097 \\
(7.60)^{\star *}\end{array}$ & $\begin{array}{l}-0.119 \\
(5.02)^{\star \star}\end{array}$ & $\begin{array}{l}-0.037 \\
(2.25)^{\star}\end{array}$ & & \\
\hline & Target U.S. by CAN. & $\begin{array}{l}-643.234 \\
(4.56)^{\star \star}\end{array}$ & $\begin{array}{l}-6.759 \\
(3.66)^{\star \star}\end{array}$ & $\begin{array}{l}-23.749 \\
(3.97)^{\star \star}\end{array}$ & $\begin{array}{l}-0.147 \\
(4.58)^{\star \star}\end{array}$ & $\begin{array}{l}-0.034 \\
(0.31)\end{array}$ & $\begin{array}{l}0.116 \\
(1.35)\end{array}$ & & \\
\hline & Target CAN by U.S. & $\begin{array}{c}-1,182.914 \\
(5.78)^{\star *}\end{array}$ & $\begin{array}{l}-9.492 \\
(5.18)^{\star \star}\end{array}$ & $\begin{array}{l}-17.714 \\
(3.06)^{\star *}\end{array}$ & $\begin{array}{l}-0.110 \\
(4.81)^{\star \star}\end{array}$ & $\begin{array}{l}-0.087 \\
(0.85)\end{array}$ & $\begin{array}{l}-0.140 \\
(2.09)^{*}\end{array}$ & & \\
\hline & R-squared & 0.14 & 0.10 & 0.14 & 0.12 & 0.06 & 0.04 & & \\
\hline \multirow{6}{*}{ (3) } & Target CAN by CAN & $\begin{array}{l}-484.966 \\
(3.03)^{\star \star}\end{array}$ & $\begin{array}{l}-3.393 \\
(1.71)+\end{array}$ & $\begin{array}{l}-8.743 \\
(2.54)^{\star}\end{array}$ & $\begin{array}{l}-0.073 \\
(5.45)^{\star \star}\end{array}$ & $\begin{array}{l}-0.145 \\
(2.49)^{*}\end{array}$ & $\begin{array}{l}-0.098 \\
(2.23)^{*}\end{array}$ & \multirow{5}{*}{ Yes } & \multirow{5}{*}{ Yes } \\
\hline & Target U.S. by U.S. & $\begin{array}{l}-862.553 \\
(9.97)^{\star \star}\end{array}$ & $\begin{array}{l}-8.202 \\
(7.03)^{\star \star}\end{array}$ & $\begin{array}{l}-14.941 \\
(5.20)^{\star *}\end{array}$ & $\begin{array}{l}-0.095 \\
(7.11)^{\star \star}\end{array}$ & $\begin{array}{l}-0.092 \\
(4.55)^{\star \star}\end{array}$ & $\begin{array}{l}-0.030 \\
(2.32)^{*}\end{array}$ & & \\
\hline & Target U.S. by CAN. & $\begin{array}{l}-506.652 \\
(3.00)^{\star *}\end{array}$ & $\begin{array}{l}-6.489 \\
(2.92)^{\star \star}\end{array}$ & $\begin{array}{l}-22.165 \\
(3.43)^{\star *}\end{array}$ & $\begin{array}{l}-0.133 \\
(4.25)^{\star \star}\end{array}$ & $\begin{array}{l}-0.025 \\
(0.29)\end{array}$ & $\begin{array}{l}0.078 \\
(1.13)\end{array}$ & & \\
\hline & Target CAN by U.S. & $\begin{array}{c}-1,161.030 \\
(5.76)^{\star *}\end{array}$ & $\begin{array}{l}-9.977 \\
(4.97)^{\star *}\end{array}$ & $\begin{array}{l}-17.917 \\
(2.82)^{\star *}\end{array}$ & $\begin{array}{l}-0.113 \\
(4.65)^{\star *}\end{array}$ & $\begin{array}{l}-0.127 \\
(1.53)\end{array}$ & $\begin{array}{l}-0.140 \\
(2.37)^{\star}\end{array}$ & & \\
\hline & R-squared & 0.27 & 0.26 & 0.21 & 0.17 & 0.24 & 0.26 & & \\
\hline & Observations & 12613 & 9080 & 5566 & 7049 & 8466 & 7956 & & \\
\hline
\end{tabular}

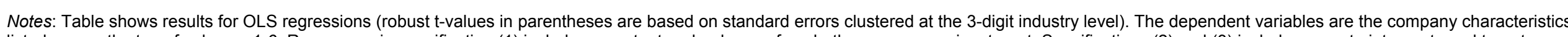
listed across the top of columns 1-6. Regressors in specification (1) include a constant and a dummy for whether a company is a target. Specifications (2) and (3) include separate intercepts and target

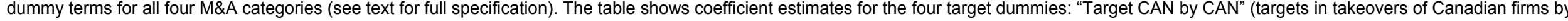

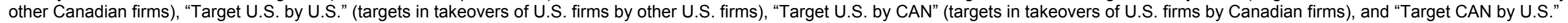

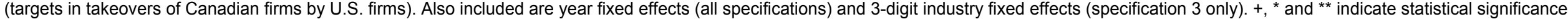
at the $10 \%$, the $5 \%$ and the $1 \%$-level, respectively. 


\section{Table 6: Firm exit via M\&A and Bankruptcy}

\begin{tabular}{lcccccc} 
& \multicolumn{2}{c}{ Canada } & \multicolumn{2}{c}{ United States } & Total \\
\hline Firms active in part or all of 1985-1997 & \multicolumn{2}{c}{331} & \multicolumn{2}{c}{5816} & & 6147 \\
Firms exiting via bankruptcy or M\&A (number and \% of active firms) & 43 & $13.0 \%$ & 1606 & $27.6 \%$ & 1649 & $26.8 \%$ \\
- Bankruptcy/Liquidation (number and \% of total exit) & 4 & $9.3 \%$ & 287 & $17.9 \%$ & 291 & $17.6 \%$ \\
- M\&A (number and \% of total exit) & 39 & $90.7 \%$ & 1319 & $82.1 \%$ & 1358 & $82.4 \%$ \\
\hline
\end{tabular}

Notes: Table shows numbers of publicly traded manufacturing firms active in all or part of 1985-1997 and total occurrences of exit via M\&A or bankruptcy among these firms.

\section{Table 7: Resource Transfer via Contraction, M\&A and Bankruptcy}

\begin{tabular}{|c|c|c|c|}
\hline Yearly Sample Averages 1985-1997 & Canada & United States & Total \\
\hline (1) Total employment ('000s) & 757.1 & 15570.2 & 16327.3 \\
\hline (2) Gross job reductions at continuing firms ('000s) & 32.5 & 745.0 & 777.6 \\
\hline (3) Job reductions through bankruptcy/liquidation ('000s) & 0.5 & 11.2 & 11.6 \\
\hline (4) Job transfers through M\&A ('000s) & 14.3 & 263.3 & 277.6 \\
\hline (5) Total job transfers ('000s) - sum of (2)-(4) & 47.3 & 1019.5 & 1066.8 \\
\hline (6) Total job transfers as \% of employment - (5)/(1) & $6.2 \%$ & $6.5 \%$ & $6.5 \%$ \\
\hline (7) M\&A as $\%$ of total job transfers $-(4) /(5)$ & $30.2 \%$ & $25.8 \%$ & $26.0 \%$ \\
\hline (1) Total output (mill. 1995 USD) & 156,764 & $3,017,341$ & $3,174,105$ \\
\hline (2) Gross output reductions at continuing firms (mill. 1995 USD) & 7,159 & 96,636 & 103,795 \\
\hline (3) Output reductions through bankruptcy/liquidation (mill. 1995 USD) & 101 & 1,374 & 1,476 \\
\hline (4) Output transfers through M\&A (mill. 1995 USD) & 3,812 & 42,744 & 46,556 \\
\hline (5) Total output transfers (mill. 1995 USD) - sum of (2)-(4) & 11,869 & 140,754 & 152,623 \\
\hline (6) Total output transfers as $\%$ of output - (5)/(1) & $7.6 \%$ & $4.7 \%$ & $4.8 \%$ \\
\hline (7) M\&A as $\%$ of total output transfers $-(4) /(5)$ & $32.1 \%$ & $30.4 \%$ & $30.5 \%$ \\
\hline
\end{tabular}

Notes: Table shows the amount of job and output transfers via contraction at continuing firms and via exit by bankruptcy/liquidation and M\&A. "Total employment" and "Total output" are obtained by summing over all firms active in a given year. "Gross job/output reductions at continuing firms" are the sum over all employment/output reductions at continuing firms as compared to the previous year.

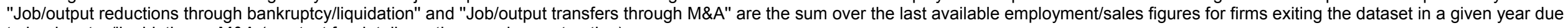
to bankruptcy/liquidation or M\&A (see text for details on the sample construction). 


\section{Figure 1: Aggregate Number of M\&A Transactions, 1985-1997}
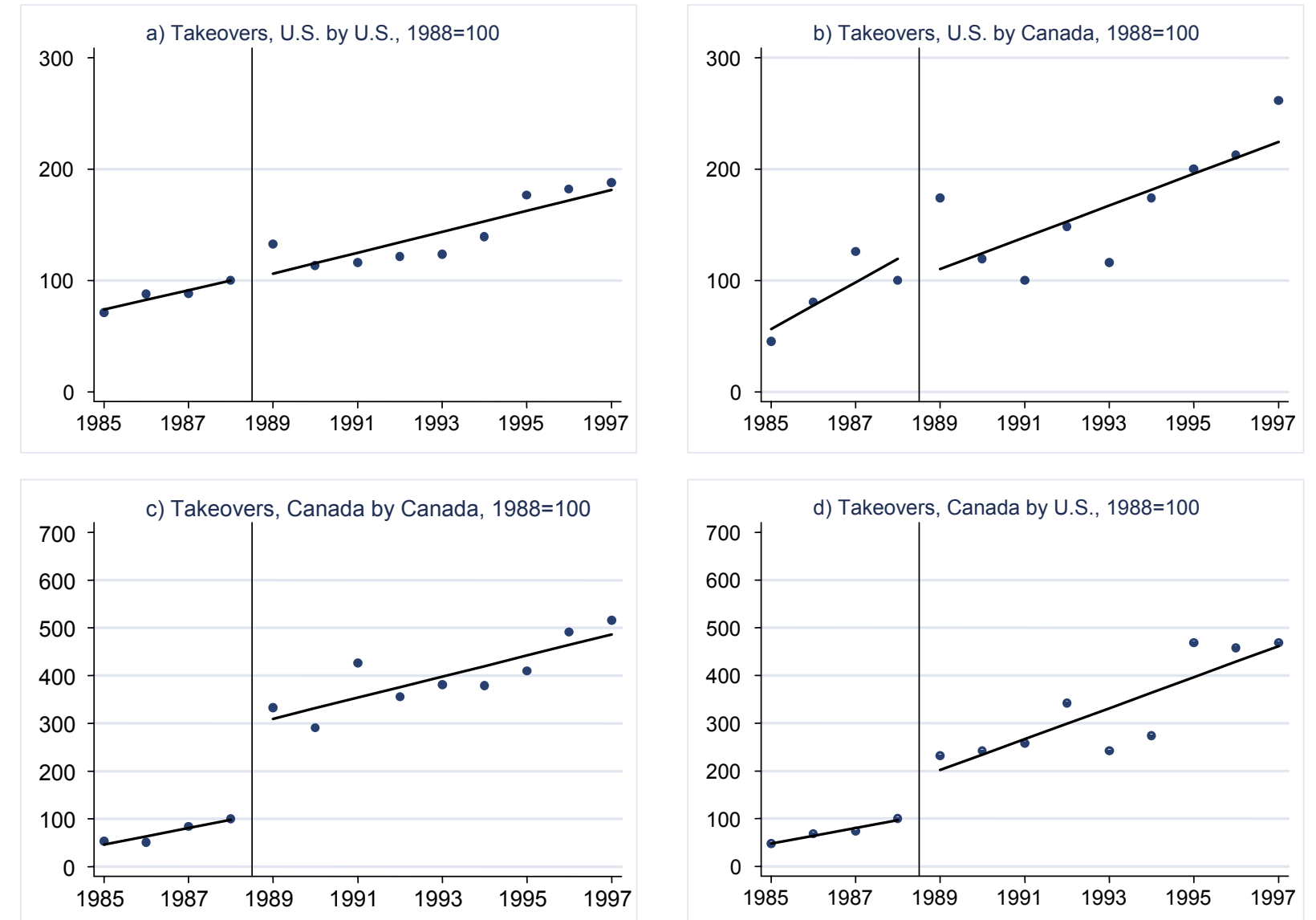

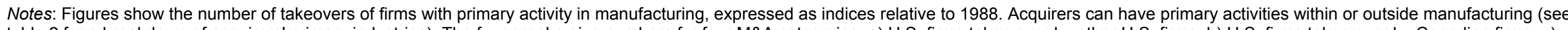

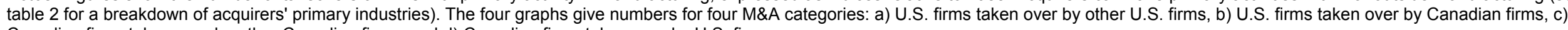
Canadian firms taken over by other Canadian firms, and d) Canadian firms taken over by U.S. firms. 


\section{Figure 2: Aggregate Number of M\&A Transactions, Most vs. Least Affected Industries}
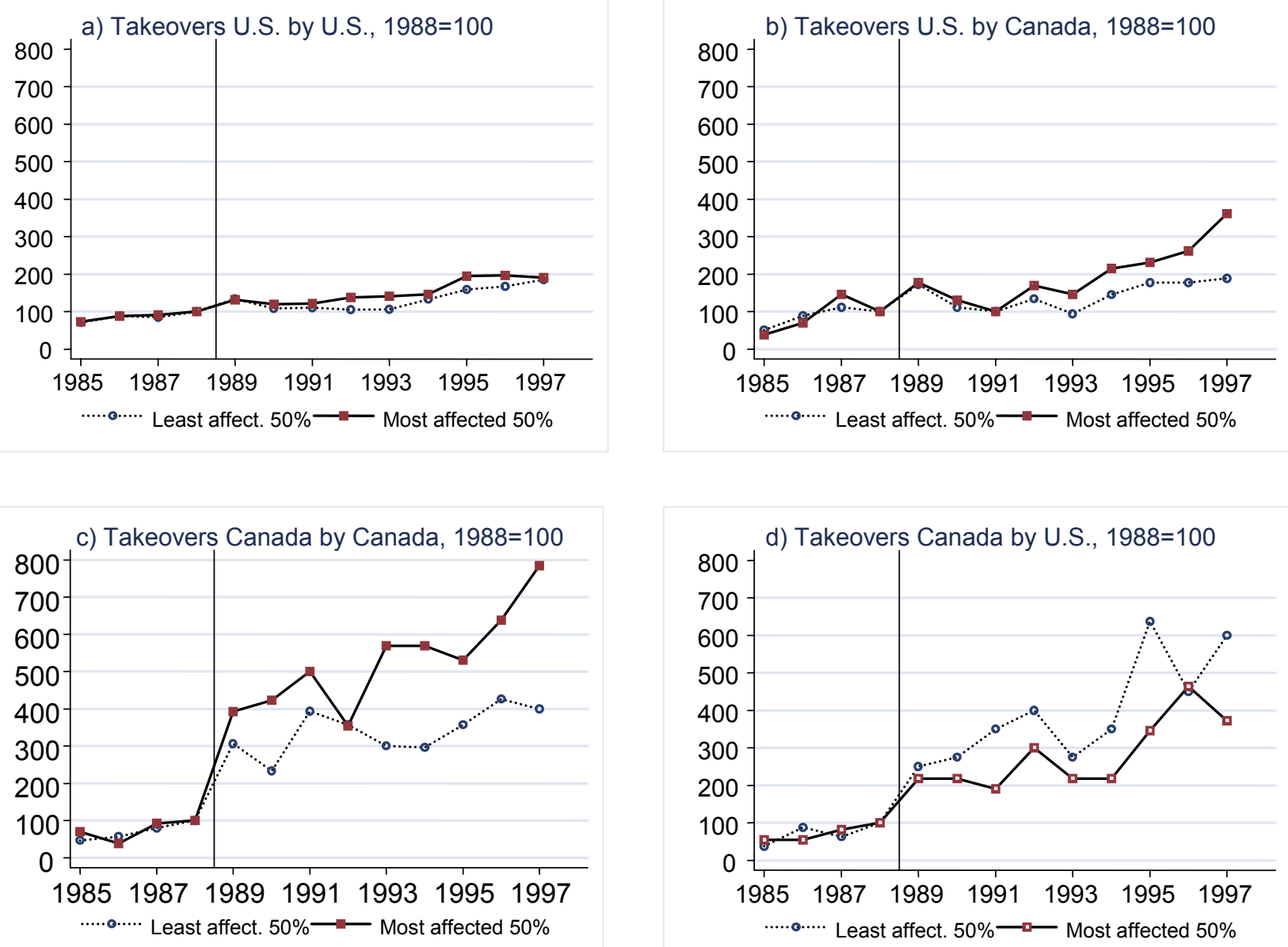

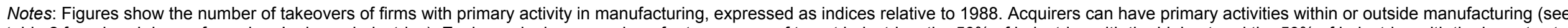

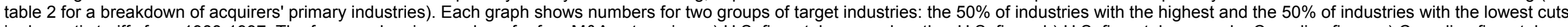

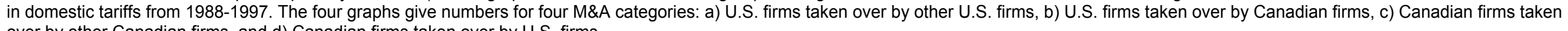
over by other Canadian firms, and d) Canadian firms taken over by U.S. firms. 


\section{A Theoretical Derivations}

\section{A.1 Entry- and Export Productivity Thresholds}

Recall that only those firms will become active for which the sum of discounted future operating profits from serving the domestic market is at least equal to the setup costs. That is, it will hold for the marginal firm that $\frac{p q}{1-\delta}-\frac{q}{\varphi} \frac{i}{1-\delta}=F i /(1-\delta)$. Similarly, for the marginal exporting firm we have $\frac{p_{x} q_{x}}{1-\delta}-\frac{q_{x}}{\varphi} \frac{i \tau}{1-\delta}=F_{x} i /(1-\delta)$. Substituing for prices $\left(p\right.$ and $\left.p_{x}\right)$ and quantities $\left(q\right.$ and $\left.q_{x}\right)$, we obtain the entry and exporting thresholds $\left(\varphi^{*}\right.$ and $\left.\varphi_{x}^{*}\right)$ as:

$$
\varphi^{*}=\left[\frac{i^{\sigma} F \sigma^{\sigma}}{P^{\sigma-1}(\sigma-1)^{\sigma-1}}\right]^{1 /(\sigma-1)}
$$

and

$$
\varphi_{x}^{*}=\left[\frac{\tau^{\sigma-1} i^{\sigma} F_{x} \sigma^{\sigma}}{P^{\sigma-1}(\sigma-1)^{\sigma-1}}\right]^{1 /(\sigma-1)}
$$

Note that the ratio of these two thresholds can be solved for $\varphi_{x}^{*}$ as:

$$
\varphi_{x}^{*}=\left(\frac{F_{x}}{F}\right)^{1 /(\sigma-1)} \tau \varphi^{*}
$$

Since every firms that wants to export has to incur both the domestic setup costs $F i /(1-$ $\delta)$ and the exporting setup costs $F_{x} i /(1-\delta)$, an exporter will always also sell on the domestic market. That is, it will hold that $\varphi_{x}^{*} \geq \varphi^{*} \cdot{ }^{37}$ On the other hand, there will be a separation into exporters and non-exporters as long as $\left(\frac{F_{x}}{F}\right)^{1 /(\sigma-1)} \tau>1$. Since there is strong evidence that such a separation is an empirically relevant phenomenon (e.g. Bernard and Jensen, 2004), I assume in the following that this condition is satisfied and that it thus holds that $\varphi_{x}^{*}>\varphi^{*}$. That is, exporting firms are always more productive than non-exporting firms.

Returning to the entry thresholds (9) and (10), I now assume that productivity levels follow a Pareto distribution (i.e. with density $v(\varphi)=a \kappa^{a} \varphi^{-(a+1)}$ with $\kappa>0, a>\sigma-1>$ 0 , and $\varphi \geq \kappa)$. With this assumption and after some algebraic manipulations, I can explicitly solve for $\varphi^{*}$ and $\varphi_{x}^{*}$ as:

$$
\varphi^{*}=\left[\frac{\sigma a \kappa^{a}}{a-\sigma+1} M_{e} F i\right]^{1 / a}\left[1+\tau^{-a}\left(\frac{F_{x}}{F}\right)^{\frac{\sigma-1-a}{\sigma-1}}\right]^{1 / a}
$$

and

\footnotetext{
${ }^{37}$ This might seem puzzling in view of condition (11) which seems to imply that $\varphi_{x}^{*}<\varphi^{*}$ for low enough values of $\frac{F_{x}}{F}$ and $\tau$. However, note that $\varphi_{x}^{*}$ is the export threshold for a firm that has already entered the domestic market (the setup costs $F i /(1-\delta)$ are not included in the zero profit condition determining $\left.\varphi_{x}^{*}\right)$.
} 


$$
\varphi_{x}^{*}=\left[\frac{\sigma a \kappa^{a}}{a-\sigma+1} M_{e} F i\right]^{1 / a}\left[\left(\frac{F_{x}}{F}\right)^{a /(\sigma-1)} \tau^{a}+\left(\frac{F_{x}}{F}\right)\right]^{1 / a}
$$

\section{A.2 Capital Demand and Prices}

With Pareto-distributed productivity levels, capital demand for domestic production and exporting at active firms can be written as:

$$
\begin{gathered}
k_{d}(\varphi)=\left[\frac{\sigma}{\sigma-1} i\right]^{-\sigma} \varphi^{\sigma-1} P^{\sigma-1}+F=(\sigma-1) F\left(\frac{\varphi}{\varphi^{*}}\right)^{\sigma-1}+F \\
k_{x}(\varphi)=\left[\frac{\sigma}{\sigma-1} i \tau\right]^{-\sigma} \varphi^{\sigma-1} P^{\sigma-1}+F_{x}=\tau^{1-\sigma}(\sigma-1) F\left(\frac{\varphi}{\varphi^{*}}\right)^{\sigma-1}+F_{x}
\end{gathered}
$$

Integrating over all active firms and using the solutions for $\varphi^{*}$ and $\varphi_{x}^{*}$ from the last section, I can determine overall capital demand for domestic production and exporting as:

$$
K_{d}=\int_{\varphi=\varphi^{*}}^{\infty} k_{d}(\varphi) M_{e} d \varphi=i^{-1}\left(\frac{a \sigma-\sigma+1}{\sigma a}\right)\left[1+\tau^{-a}\left(\frac{F_{x}}{F}\right)^{\frac{\sigma-a-1}{\sigma-1}}\right]^{-1}
$$

and

$$
K_{x}=\int_{\varphi=\varphi_{x}^{*}}^{\infty} k_{x}(\varphi) M_{e} d \varphi=i^{-1}\left(\frac{a \sigma-\sigma+1}{\sigma a}\right)\left[1+\tau^{a}\left(\frac{F_{x}}{F}\right)^{-\frac{\sigma-a-1}{\sigma-1}}\right]^{-1}
$$

Finally, using the M\&A market clearing condition $K_{d}+K_{x}=K$, I can solve for $i$ as:

$$
i=K^{-1}\left(\frac{a \sigma-\sigma+1}{\sigma a}\right)
$$

Plugging this result back into (12) and (13), I obtain the results for $K_{d}$ and $K_{x}$ presented in the main text. 


\section{B Linking Tariff and M\&A Data}

The tariff data are constructed as described in Head and Ries (1999). U.S. tariffs prior to CUSFTA are taken from Government of Canada (1988), Canadian tariffs from Lester and Morehen (1987). These publications provide tariffs for around 100 industries, roughly corresponding to the 3-digit level of the Canadian industry classification of 1980 (CANSIC80). Tariff reductions after 1988 are calculated by determining to which so-called 'staging' category an industry had been assigned under CUSFTA. The staging category agreed upon determined the rate by which tariff protection was being phased out. Most industries had their tariffs reduced in equal parts from 1989 to 1997. A smaller number were placed on a five year phase-out and a handful opted for immediate elimination. Note that the above two publications do not provide data for 1985 and 1986. However, Lester and Morehen (1987) does contain Canadian tariffs for 1979 which I interpolate to 1987 to get some impression of tariff changes in that period. As other studies (e.g. Gu et al., 2003), I find changes in 1985-1988 to be small both in absolute terms and compared to the subsequent cuts implemented via CUSFTA. In my econometric analysis (sections 5.2 and 5.3), I will thus set the pre-CUSFTA change in tariffs equal to zero. Using my interpolated data for the regressions involving Canadian tariff cuts yields very similar results to the ones presented in this paper (with the exception of the binary measure for most-least affected industries which shows too little variation over time - $80 \%$ of industries stay in the same group pre and post CUSFTA).

In order to link the tariff data to the data on M\&A transactions, I assign each M\&A deal to a 4-digit category of the 1987 U.S. industry classification (US-SIC87) based on the primary field of activity of the target company or division. In order to determine the tariff facing that industry, I use a correspondence between CAN-SIC80 and US-SIC87 provided by Statistics Canada. The mapping was unique in about $70 \%$ of cases in the sense that a U.S.-industry was matched to a unique tariff rate. For the remaining 30\%, I used averages of tariffs weighted according to the average number of establishments in the CAN-SIC80 category (this arguably captures the "M\&A potential" of an industry better than e.g. value added or output weights would do: ceteris paribus, a transaction is more likely to occur in an industry with more establishments; however, using simple averages does not qualitatively affect my results). Finally, I aggregated the U.S.-data up to the 3-digit level (140 industries), again using the number of firms in a 4-digit category as tariff weights. This aggregation was done in order to reduce the number of zero-transaction industries (thus mitigating problems of an excess number of zeros in the fixed effects Poisson regressions) and to reflect more accurately the less disaggregated nature of the underlying tariff data. 


\section{References}

[1] Andrade, G., M. Mitchell and E. Stafford (2001), "New Evidence and Perspectives on Mergers", Journal of Economic Perspectives, 15, 103-120.

[2] Andrade, G. and E. Stafford (2004), "Investigating the Economic Role of Mergers", Journal of Corporate Finance, 10, 1-36.

[3] Baggs, J. (2004), "Changing Trade Barriers and Canadian Firms: Survival and Exit After the Canada-U.S. Free Trade Agreement", Analytical Studies Branch Research Paper 205, Statistics Canada.

[4] Bernard, A.B., J. Eaton, J.B. Jensen and S.S. Kortum (2003), "Plants and Productivity in International Trade", American Economic Review, 93(4), 1268-1290.

[5] Bernard, A. and J.B. Jensen (2004), "Why some firms export", Review of Economics and Statistics, 86, 561-569.

[6] Bernard, A., S. Redding and P. Schott (2004), "Comparative Advantage and Heterogeneous Firms", NBER Working Paper 10668.

[7] Bertrand, O. and H. Zitouna (2005), "Trade Liberalization and Industrial Restructuring: The Role of Cross-Border Mergers and Acquisitions", Journal of Economics and Management Strategy, forthcoming.

[8] Bjornvatn, Kjetil (2004), "Economic Integration and the Profitability of CrossBorder Mergers and Acquisitions", European Economic Review, 48, 1211-1226.

[9] Brealey, R. and S. Myers (2000), Principles of Corporate Finance, McGraw-Hill.

[10] Cabral, L. and J. Mata (2001), "On the Evolution of the Firm Size Distribution: Facts and Theory", CEPR Discussion Paper 3045. Forthcoming, American Economic Review.

[11] Cameron, A. and P. Trivedi (1998), Regression Analysis of Count Data, Cambridge University Press.

[12] Canadian Competition Bureau (1991), "Merger Enforcement Guidelines 1991", available at http://www.competitionbureau.gc.ca.

[13] Canadian Competition Bureau (2002), "Merger Enforcement Guidelines 2002", available at http://www.competitionbureau.gc.ca.

[14] Chudnovsky, D. (2000): "Industrial restructuring through mergers and acquisitions: The case of Argentina in the 1990s," Transnational Corporations, 9, 33-58.

[15] Copeland, T., F. Weston, K. Shastri (2003), Financial Theory and Corporate Policy", Addison-Wesley, Boston.

[16] Davis, S., J. Haltiwanger, and S. Schuh (1996), Job creation and destruction, MIT Press, Cambridge, Mass. 
[17] di Giovanni, J. (2005), "What Drives Capital Flows? The Case of Cross-Border M\&A Activity and Financial Deepening", Journal of International Economics, 65, 127-149.

[18] Dutz, M. (1989), "Horizontal Mergers in Declining Industries - Theory and Evidence", International Journal of Industrial Organization, 7, 11-33.

[19] Falvey, R., D. Greenaway and Z. Yu (2004), "Intra-Industry Trade between Asymmetric Countries with Heterogeneous Firms", GEP Research Paper 2004/05, University of Nottingham.

[20] Fernandes, A. (2003), "Trade Policy, Trade Volumes and Plant Level Productivity in Colombian Manufacturing Industries", World Bank Policy Research Working Paper 3064 .

[21] Görg, Holger (2000), "Analysing Foreign Market Entry: The Choice between Greenfield Investment and Acquisitions", Journal of Economic Studies, 27(3), 473-486.

[22] Government of Canada, Department of Finance (1988), "Trade Barriers Between Canada and the United States", Department of Finance Working Papers.

[23] Greenaway, D., J. Gullstrand and R. Kneller (2005), "Surviving Globalisation", GEP Research Paper 2005/19, University of Nottingham.

[24] Gu, W., G. Sawchuk and L. Whewell (2003), "The Effect of Tariff Reductions on Firm Size and Firm Turnover in Canadian Manufacturing", Economic Analysis Research Paper 014, Statistics Canada.

[25] Gugler, K., D.C. Mueller and B.B. Yurtoglu (2004), "The Determinants of Merger Waves", mimeo, University of Vienna.

[26] Head, K. and J. Ries (1999), "Rationalization Effects of Tariff Reductions", Journal of International Economics, 47(2), 295-320.

[27] Horn, H., and L. Persson (2001): "The Equilibrium Ownership of an International Oligopoly," Journal of International Economics, 53, 307-333.

[28] Jensen, M. (1993), "The Modern Industrial Revolution, Exit, and Control Systems", Journal of Finance, 48, 831-880.

[29] Jovanovic, B. and P. Rousseau (2002), "The Q-Theory of Mergers," American Economic Review, 92, 198-204.

[30] Jovanovic, B. and P. Rousseau (2004), "Mergers as Reallocation", mimeo, Vanderbilt University.

[31] Kaplan, S. (ed., 2000), Mergers and Productivity, NBER Conference Report, University of Chicago Press, Chicago.

[32] Lester, J. and T. Morehen (1987), "New Estimates of Canadian Tariff Rates by Industry and Commodity", Canadian Department of Finance Working Paper No. $88-2$. 
[33] Maksimovic, V. and G. Phillips (2001), "The Market for Corporate Assets: Who Engages in Mergers and Asset Sales and Are There Efficiency Gains?", Journal of Finance, 56(6), 2019-2065.

[34] Melitz, M.J. (2003), "The Impact of Trade on Intra-Industry Reallocations and Aggregate Industry Productivity", Econometrica, 71, 1695-1725.

[35] Melitz, M.J. and G.I.P. Ottaviano (2005), "Market Size, Trade, and Productivity", mimeo, Harvard University.

[36] Mitchell, M. and J. Mulherin (1996), "The Impact of Industry Shocks on Takeover and Restructuring Activity", Journal of Financial Economics, 41, 193-299.

[37] Morck, R., D. Strangeland and B. Yeung (1998), "Inherited Wealth, Corporate Control and Economic Growth: The Canadian Disease?", NBER Working Paper 6814.

[38] Mulherin, J. and A. Boone (2000), "Comparing Acquisitions and Divestitures", Journal of Corporate Finance, 6, 117-139.

[39] Neary, P.J. (2005), "Cross-Border Mergers as Instruments of Comparative Advantage", mimeo, University College Dublin.

[40] Nocke, V. and S. Yeaple (2004), "Mergers and the Composition of International Commerce", NBER Working Paper 10405.

[41] OECD (2001), New Patterns of Industrial Globalisation: Cross-border mergers and acquisitions and strategic alliances, Organisation for Economic Co-operation and Development, Services and Trade group, Paris.

[42] Pavcnik, N, (2002), "Trade Liberalization, Exit, and Productivity Improvements: Evidence from Chilean Plants", Review of Economics and Statistics, 69, 245-276.

[43] Roberts, M.J. and J.R. Tybout (1997), "What Makes Exports Boom?", Directions in Development Series, World Bank, Washington D.C.

[44] Rodríguez, F. and D. Rodrik (1999), "Trade Policy and Economic Growth: A Skeptic's Guide to the Cross-National Evidence", NBER Working Paper No. 7081.

[45] Santos Silva, J. and S. Tenreyro (2004), "The Log of Gravity", mimeo, London School of Economics.

[46] Topalova, P. (2004), "Trade Liberalization and Firm Productivity: The Case of India", IMF Working Paper 04/28.

[47] Trefler, D. (2004), "The Long and Short of the Canada-U.S. Free Trade Agreement", American Economic Review, 94(4), 870-895.

[48] Tybout, J.R., J. de Melo and V. Corbo (1991), "The Effects of Trade Reforms on Scale and Technical Efficiency", Journal of International Economics, 31(3-4), 231-50.

[49] Tybout, J., 2001, Plant and Firm-Level Evidence on New Trade Theories, NBER Working Paper 8418. 
[50] Tybout, J.R. and Westbrook, M.D. (1995), "Trade Liberalization and the Dimensions of Efficiency Change in Mexican Manufacturing Industries", Journal of International Economics, 39(1-2), 53-78.

[51] Wooldridge, J.M. (1999), "Distribution-free Estimation of some nonlinear Panel Data Models", Journal of Econometrics, 90, 77-97.

[52] Wooldridge, J.M. (2002), Econometric Analysis of Cross Section and Panel Data, MIT Press, Cambridge, Massachusetts. 


\section{CENTRE FOR ECONOMIC PERFORMANCE Recent Discussion Papers}

716 Nick Bloom

John Van Reenen

715 Mirko Draca

Stephen Machin

John Van Reenen

714 Matteo Bugamelli

Francisco Paternò

713 Alex Bryson

712 Marco Manacorda

Carolina Sanchez-Paramo

Norbert Schady

711 Claudia Olivetti

Barbara Petrongolo

710 Hilary Steedman

709 Florence Kondylis

708 David Metcalf

Jianwei Li

707 Richard Walker

706 Miklós Koren

Silvana Tenreyro

705 Andy Charlwood

704 Michael W. L. Elsby
Measuring and Explaining Management Practices

Across Firms and Countries

Minimum Wages and Firm Profitability

Do Workers' Remittances Reduce the Probability of Current Account Reversals?

Union Free-Riding in Britain and New Zealand

Changes in Returns to Education in Latin America: the Role of Demand and Supply of Skills

Unequal Pay or Unequal Employment? A CrossCountry Analysis of Gender Gaps

Apprenticeship in Europe: 'Fading' or Flourishing?

Agicultural Returns and Conflict: Quasi-Experimental Evidence from a Policy Intervention Programme in Rwanda

Chinese Unions: Nugatory or Transforming? An Alice Analysis

Superstars and Renaissance Men: Specialization, Market Size and the Income Distribution

Volatility and Development

The De-Collectivisation of Pay Setting in Britain 1990-1998: Incidence, Determinants and Impact

Evaluating the Economic Significance of Downward Nominal Wage Rigidity 
703 David Marsden

Richard Belfield

702 John Van Reenen

701 Joas Santos Silva

Silvana Tenreyro

700 Alan Manning Joanna Swaffield

699 Andrew B. Bernard Stephen Redding

Peter K. Schott

698 Nicholas Oulton

697 Alan Manning

696 Andrew B. Bernard Stephen Redding Peter K. Schott

695 Henry G. Overman Anthony J. Venables

694 Carlo Rosa

Giovanni Verga

693 Richard Dickens

Mirko Draca

692 Ralf Martin

691 Augustin de Coulon François-Charles Wolff
Performance Pay for Teachers Linking Individual and Organisational Level Targets

The Growth of Network Computing: Quality Adjusted Price Changes for Network Servers

The Log of Gravity

The Gender Gap in Early Career Wage Growth

Products and Productivity

Ex Post Versus Ex Ante Measures of the User Cost of Capital

You Can't Always Get What You Want: the Impact of the Jobseeker's Allowance

Factor Price Equality and the Economies of the United States

Cities in the Developing World

The Importance of the Wording of the ECB

The Employment Effects of the October 2003

Increase in the National Minimum Wage

Computing the True Spread

Immigrants at Retirement: Stay/Return or 'Va-etVient'?

The Centre for Economic Performance Publications Unit Tel 02079557673 Fax $02079557595 \quad$ Email info@cep.lse.ac.uk Web site http://cep.lse.ac.uk 